\title{
Metabolism and biochemical characteristics of yogurt bacteria. A review
}

\author{
A Zourari *, JP Accolas, MJ Desmazeaud \\ Station de Recherches Laitières, INRA, 78352 Jouy-en-Josas Cedex, France
}

(Received 5 July 1991; accepted 1st October 1991)

\begin{abstract}
Summary - This review reports recent data regarding the metabolism and biochemistry of Streptococcus salivarius subsp thermophilus and Lactobacillus delbrueckii subsp bulgaricus related to yogurt manufacture. The taxonomy of these bacteria is presented. Different proposed pathways for carbohydrate metabolism are then discussed, as well as recent molecular and genetic studies of the enzymes involved. Acetaldehyde is the major aromatic compound in yogurt, and so the different pathways of its formation are briefly described. Recent studies have concerned threonine aldolase which catalyzes acetaldehyde synthesis by yogurt bacteria. Exocellular polysaccharides produced by lactic acid bacteria improve the texture of stirred and liquid yogurts. Some of the polysaccharides of yogurt bacteria are currently known and particular aspects of their production are discussed. Some other properties, ie proteolysis, lipolysis, urease, oxygen metabolism, are also briefly presented. Interactions between streptococci and lactobacilli are well established, but more data are required for the complete characterization and control of mixed populations. In particular, little is known about antimicrobial compounds produced by these microorganisms. Bacteriophages of yogurt bacteria are now well characterized, but little is known about lysogeny in thermophilic streptococci. Finally, progress in genetics (on both plasmid and chromosomal DNA) is briefly discussed.
\end{abstract}

Streptococcus salivarius subsp thermophilus / Lactobacillus delbrueckii subsp bulgaricus / yogurt / metabolism / interaction

Résumé - Métabolisme et caractéristiques biochimiques des bactéries du yaourt. Une revue. Dans le présent article, la position taxonomique de Streptococcus salivarius subsp thermophilus et de Lactobacillus delbrueckii subsp bulgaricus est d'abord décrite. Les différentes voies du métabolisme des glucides sont discutées ainsi que les études récentes des enzymes impliquées, sur le plan moléculaire et génétique. L'acétaldehyde est le composé caractéristique de l'arôme typique du yaourt. Les différentes voies métaboliques de sa synthèse sont brièvement décrites, en particulier celle qui met en jeu la thréonine aldolase. Les bactéries lactiques produisent des polysaccharides exocellulaires qui influencent la texture des yaourts brassés et des yaourts liquides. Des polysaccharides produits par les bactéries du yaourt sont maintenant connus et quelques aspects intéressants de leur production sont actuellement étudiés. D'autres activités (protéolyse, lipolyse, uréase, métabolisme de l'oxygène) sont aussi brièvement présentées, suite à plusieurs études récentes. Les interactions entre streptocoques et lactobacilles sont bien établies, mais davantage de données sont nécessaires pour la caractérisation complète et la maîtrise des populations mixtes. En particulier, les connaissances des substances antimicrobiennes produites par les bactéries du

- Present address: Boll-Groupe Chr Hansen, Le Moulin d'Aulnay, BP 64, 91292 Arpajon Cedex, France 
yaourt sont encore limitées. Les bactériophages de ces bactéries sont maintenant relativement bien caractérisés mais les données sur la lysogénie du streptocoque demeurent encore incomplètes. Enfin, le progrès des études génétiques (ADN plasmidique et chromosomique) est brièvement discuté.

Streptococcus salivarius subsp thermophilus / Lactobacillus delbrueckii subsp bulgaricus / yaourt / métabolisme / interaction

\section{CONTENTS}

Introduction 2

Taxonomy 2

S salivarius subsp thermophilus $\quad 2$

L delbrueckii subsp bulgaricus 3

Important metabolic activities for yogurt technology 4

Acid production - Carbohydrate metabolism 4

Carbohydrate metabolism of $S$ thermophilus $\quad 5$

- Lactose and galactose transport 5

- Metabolic pathways of lactose, glucose and galactose 6

- Sucrose utilization 6

Carbohydrate metabolism of $L$ bulgaricus $\quad 8$

Lactic acid isomers in yogurt $\quad 8$

Formation of flavour compounds 9

Flavour compounds of yogurt $\quad 9$

Metabolic pathways of acetaldehyde synthesis $\quad 9$

- Formation of acetaldehyde from glucose 9

- Formation of acetaldehyde from threonine $\quad 10$

- Formation of acetaldehyde from DNA components $\quad 10$

- Alcohol dehydrogenase $\quad 11$

Production of polysaccharides $\quad 11$

Other metabolic activities 12

$\begin{array}{ll}\text { Proteolytic activity } & 12\end{array}$

Amino acids in milk and yogurt $\quad 12$

Utilization of proteins $\quad 12$

Utilization of peptides $\quad 13$

Lipolytic activity 13

Urease activity 14

Oxygen and metabolism $\quad 14$ 
Particular aspects of yogurt fermentation

Interactions between yogurt bacteria

Production of antimicrobial compounds by yogurt bacteria 16

Bacteriophages of $\mathrm{L}$ bulgaricus and $\mathrm{S}$ thermophilus $\quad 17$

Genetics of S thermophilus and L bulgaricus 21

Conclusion 23

References $\quad 24$

\section{INTRODUCTION}

Yogurt and similar fermented milk products have been very popular for a long time in Mediterranean countries (the Balkans, North Africa), in central and southwest Asia (Mongolia, Turkey, Iraq, Iran, Syria) and in central Europe. In many of these countries, yogurt is still manufactured using traditional procedures. Since the last world war, yogurt consumption has been steadily increasing not only in European countries, but also in the United States, enhancing its industrial-scale production. At present, new types of fermented milk are available, prepared by adding fruits or flavouring, enriched with vitamins or containing selected intestinal bacteria such as Lactobacillus acidophilus and several Bifidobacterium species (Kurmann, 1984; Puhan, 1988).

In France, the term "yogurt" can be used legally only to designate the product resulting from milk fermentation brought about exclusively with 2 thermophilic lactic acid bacteria, Streptococcus salivarius subsp thermophilus and Lactobacillus delbrueckii subsp bulgaricus, which must be found alive in the final product $(\approx 10$ million cfu. $g^{-1}$ of yogurt). It is noteworthy that these 2 conditions are seldom specified by existing legislation in most other yogurtproducing countries (Anonymous, 1989).

We review here recent data on some of the metabolic and biochemical aspects of these starter bacteria in relation to yogurt manufacture. Tamime and Deeth (1980) have published an excellent review concerning all the technological and biochemical aspects of yogurt, followed by a second article dealing with its nutritional and therapeutic properties (Deeth and Tamime, 1981). These reviews include a detailed presentation of $S$ salivarius subsp thermophilus and $L$ delbrueckii subsp bulgaricus. Since 1981, both microorganisms have been extensively studied and reviews dealing with particular aspects of their metabolism and genetics have been published (Hutkins and Morris, 1987; Mercenier and Lemoine, 1989; De Vos, 1990; Mercenier, 1990). The present review is an update in this field and will give the technological and biochemical context of yogurt manufacture. Emphasis is put on bacteria and not on yogurt and only limited information concerning yogurt manufacture will be reported. 


\section{TAXONOMY OF S SALIVARIUS SUBSP THERMOPHILUS AND L DELBRUECKII SUBSP BULGARICUS}

\section{S salivarius subsp thermophilus}

$S$ salivarius subsp thermophilus is the new name proposed to designate Streptococcus thermophilus which was originally described by Orla-Jensen (1919) and which stands apart from the other streptococci and especially lactic streptococci, at present designated as lactococci. It is exclusively isolated from the dairy environment, ferments only few carbohydrates, ie lactose, sucrose, glucose and sometimes galactose, and is characterized by its thermoresistance and a rather high growth temperature which may reach $50-52{ }^{\circ} \mathrm{C}$. No group-specific antigen has been found (Hardie, 1986).

DNA-DNA homology studies might supply more information on this bacterium and may question its classification. The guanosine plus cytosine content ( $\mathrm{mol} \mathrm{G}+\mathrm{C} \%$ ) of DNA ranges from $37.2-40.3 \%$ according to Farrow and Collins (1984). These authors obtained $61-78 \%$ homology between DNA of several $S$ thermophilus strains and a DNA probe of Streptococcus salivarius (the homology between DNA of $S$ salivarius strains and a DNA probe of $S$ thermophilus ranged from $67-91 \%$ ). They thus confirmed the high DNA homology (70$100 \%$ ) observed in an earlier study by Kilpper-Bälz et al (1982) for 2 strains of each species. On the basis of these results, Farrow and Collins (1984) proposed that $S$ thermophilus should be reclassified as a subspecies of $S$ salivarius despite the large phenotypic differences between these 2 bacteria. In fact, lactate dehydrogenases of the type-strains of both streptococci have different properties (Garvie,
1978). Furthermore, the thermoresistance of their fructose-diphosphate aldolases is different, as is their level of homology with Enteroccocus faecalis aldolase assessed by immunodiffusion assays, in spite of very close migration distances (London and Kline, 1973).

In addition, Garvie and Farrow (1981) had previously placed these streptococcal strains in the same group, based on homology between their DNA and ribosomal RNA of the type-strain of Streptococcus bovis (this strain now belongs to the Streptococcus equinus species; Schleifer and Kilpper-Bälz, 1987), but in different clusters. Besides, DNA-DNA molecular hybridization between several strains of $S$ thermophilus and $S$ salivarius have only yielded a $60 \%$ homology in optimum conditions and $30 \%$ under stringent hybridization conditions (Schleifer and Killper-Bälz, 1987). Based on recent hybridization data, phenotypic differences and occurrence in completely different biotopes (mouth/milk), Schleifer and Kilpper-Bälz (1987) suggested maintaining $S$ thermophilus and $S$ salivarius as 2 separate species. It is obvious that the taxonomy of $S$ thermophilus requires further discussion and that more data are required before reaching a definitive decision.

Colmin et al (1991) developed a DNA probe which specifically hybridized to 25 strains of subspecies thermophilus and to 2 strains of subspecies salivarius of $S$ salivarius. This cross-hybridization suggests that both species share common DNA sequences, but more data are needed to support a possible close relationship between these 2 streptococci. In addition, the probe easily detects RFLP (restriction fragment length polymorphism) in $S$ thermophilus and accordingly can be used for strain characterization. 


\section{L delbrueckii subsp bulgaricus}

This lactobacillus was first described by Orla-Jensen (1919) and named Thermobacterium bulgaricum. It is presently considered as one of the subspecies of Lactobacillus delbrueckii. Two other subspecies, subsp delbrueckii and subsp lactis, also belong to this group. The old terminology Lactobacillus leichmannii is no longer in use.

L delbrueckii subsp bulgaricus is homofermentative, ferments few carbohydrates, ie glucose, lactose, fructose, and sometimes galactose or mannose, and has a high growth temperature (up to 48 or 50 $\left.{ }^{\circ} \mathrm{C}\right)$. Its DNA mol G $+\mathrm{C} \%$ ranges from 49 to $51 \%$ (Kandler and Weiss, 1986).

Simonds et al (1971) obtained a DNA homology of $86 \%$ between the former $L$ bulgaricus and $L$ lactis species, but only $4.8 \%$ with Lactobacillus helveticus and no homology with $L$ helveticus var jugurti. This was confirmed by Dellaglio et al (1973) who obtained $<7 \%$ DNA homology between $L$ bulgaricus and $L$ helveticus or $L$ helveticus var jugurti. The study of Weiss et al (1983) showed 80 to $100 \%$ homology (90-100\% for type-strains) between the former $L$ bulgaricus, $L$ leichmannii, $L$ lactis and $L$ delbrueckii species. DNA homology led to the reclassification of these 4 lactobacilli as subspecies of $L$ delbrueckii in the most recent classification of Bergey's Manual (Kandler and Weiss, 1986).

A specifc DNA probe for $L$ delbrueckii has been developed recently, which makes it possible to differentiate this species from other lactobacilli, lactococci and propionibacteria (Delley et al, 1990).

In the present article, we shall use the former names of the yogurt organisms, ie $S$ thermophilus and $L$ bulgaricus for purposes of convenience.

\section{IMPORTANT METABOLIC ACTIVITIES FOR YOGURT TECHNOLOGY}

The role of streptococci and lactobacilli in yogurt manufacture can be summarized as follows: milk acidification, synthesis of aromatic compounds, development of texture and viscosity. The latter aspect is required mainly for stirred and liquid yogurts. Thus, for industrial yogurt manufacture, starter selection takes into account these 3 properties. Evaluation of acidification properties is difficult because of the high buffering capacity of milk and the lack of a standard procedure. Efforts have been made to develop new methods for an objective evaluation of strains in replacement of former procedures (eg that of Accolas et al, 1977) based on the measurement of titratable acidity in milk. For example, the method patented by Corrieu et al (1989), and described by Spinnler and Corrieu (1989), uses continuous automatic recording of $\mathrm{pH}$ during bacterial growth in milk and the strains are compared on the basis of maximum acidification rates and the corresponding time and $\mathrm{pH}$. In the field of industrial preparation of mixed starter cultures, efforts have been made to control the growth of streptococcus and lactobacillus populations by culture conditions, $\mathrm{pH}$ and temperature (Béal et al, 1989). Chamba and Prost (1989) evaluated the acidifying properties of strains used for cheesemaking, based on $\mathrm{pH}$ measurements during growth following the temperature profile of a standard cheesemaking operation.

The evaluation of aroma formation is generally based on the production of acetaldehyde, a major aromatic compound of yogurt, whereas the thickening character is based on measurements of milk viscosity (Bouillanne and Desmazeaud, 1980, 1981; Zourari et al, 1991; Zourari and Desmazeaud, 1991). 
In the first part of this review, we present the metabolic activities responsible for the acidification, flavouring and thickening properties of yogurt bacteria. We then describe some metabolic activities of lesser importance for yogurt manufacture, but which determine the growth of bacteria in milk and their interactions, ie proteolysis, lipolysis, urease activity, oxygen effect.

\section{Acid production. Carbohydrate metabolism}

The main role of $S$ thermophilus and $L$ bulgaricus in yogurt manufacture is to acidify milk by producing a large amount of lactic acid from lactose. Lactic acid reduces the $\mathrm{pH}$ of the milk and leads to a progressive solubilization of micellar calcium phosphate. This causes the demineralization of casein micelles and their destabilization, which generates the complete precipitation of casein in a $\mathrm{pH}$ range of 4.6-4.7 (Fox, 1989). In addition, lactic acid provides yogurt with its sharp, acid taste and contributes to flavour.

Lactic acid production may also occur during yogurt storage at low temperature. It may lead to an excessive acidification which affects the organoleptic properties of the product. This activity depends on the strains used and especially on the lactobacilli (Accolas et al, 1977; Bouillanne and Desmazeaud, 1980, 1981).

\section{Carbohydrate metabolism of $S$ thermophilus}

\section{Lactose and galactose transport}

The mechanism of lactose transport in $S$ thermophilus differs from that of lactococci, which possess a specific system for lactose transport, the phosphoenolpyruvate (PEP)-dependent phosphotransfe- rase system (PTS). Lactose-6-phosphate formed during transport is hydrolyzed by an intracellular phospho- $\beta$-galactosidase into glucose and galactose-6-phosphate which are then metabolized into lactic acid (Thomspon, 1987). S thermophilus does not possess lactose PTS or phospho- $\beta$ galactosidase (Tinson et al, 1982a; Thomas and Crow, 1984), but has a lactose permease system including a protondependent membrane-located permease and an intracellular $\beta$-galactosidase (Poolman et al, 1989).

The lactose permease gene of $S$ thermophilus (lacS) was cloned and expressed in Escherichia coli (Poolman et al, 1989). The comparison of amino acid sequences showed that the streptococcal lactose transport protein (LacS) differs from the lactose permease of $E$ coli (LacY) and appears to be a hybrid protein of $69 \mathrm{kDa}$. The $\mathrm{NH}_{2}$-terminal region is homologous with the melibiose carrier (MelB) of $E$ coli $(23 \%$ overall similarity) whereas the $\mathrm{COOH}$ terminal end is partially homologous (34$41 \%$ ) with enzyme III ( $E$ III) of 3 different PEP-PTS systems.

Galactose seems to be directly involved in lactose transport. In fact, the presence of a large amount of galactose in the growth medium inhibits lactose transport (Somkuti and Steinberg, 1979). Biochemical studies have shown that galactose has a considerable affinity for lactose permease and acts as a competitive inhibitor of the lactose transport system (Hutkins and Morris, 1987), but more recent data supply another explanation. In membrane vesicles of $E$ coli, lacS permease not only catalyzes a proton motive force-linked transport system, but also exchange of $\beta$ galactosides. This means that the lactose transport reaction proceeds as a lactosegalactose antiport independent of the proton motive force (Poolman et al, 1989; Hutkins and Ponne, 1991). 
Galactose transport requires an exogenous energy source and involves the action of a galactose permease. A PEP-PTSlike system has not been detected in $S$ thermophilus. Glucose and galactose transport is slower than that of lactose (Hutkins et al, 1985a). The preferential utilization of lactose could be due to limitations in monosaccharide transport (Somkuti and Steinberg, 1979). In light of the involvement of galactose in lactose transport, however, these data should be re-evaluated.

Metabolic pathways of lactose, glucose and galactose utilization

Figure 1 summarizes the proposed pathways for lactose and galactose transport and their utilization by $S$ thermophilus. Intracellular $\beta$-galactosidase ( $\beta$-gal) hydrolyzes lactose to glucose and galactose. Glucose represses synthesis of this enzyme (Tinson et al, 1982a). Streptococcal $\beta$-gal has been purified and characterized (Ramana Rao and Dutta, 1981; Greenberg and Mahoney, 1982; Smart et al, 1985). The $\beta$-gal-encoding gene has been cloned and expressed in Ecoli (Herman and McKay, 1986) and in Saccharomyces cerevisiae (Lee et al, 1990). Streptococcal $\beta$ gal is a protein of about $105 \mathrm{kDa}$ and the $\beta$-gal-encoding gene is located in a $3.85-k b$ region of the chromosomal DNA (Herman and McKay, 1986). This enzyme is useful as a potential selective marker in foodgrade cloning vectors, and also for its possible industrial production because of its higher thermostability compared to currently produced yeast enzymes.

The glucose moiety of lactose is directly used via the Embden-Meyerhof-Parnas pathway (fig 1). $S$ thermophilus possesses 2 fructose-1,6-diphosphate-independent (FDP-independent) lactate dehydrogenases (LDH) which reduce pyruvate to lactic acid (Garvie, 1978).
The galactose moiety is released into the extracellular medium by most $S$ thermophilus strains which are not able to use it, ie Gal- phenotype (Hutkins and Morris, 1987). Gal+ strains have been isolated (Somkuti and Steinberg, 1979; Thomas and Crow, 1984), however, in which galactose is metabolized via the Leloir pathway involving the enzymes galactokinase, galactose-1-phosphate-uridyl transferase and uridine-5-diphospho-glucose-4-epimerase. The 2 latter enzymes are constitutive and present in $\mathrm{Gal}^{-}$as well as in $\mathrm{Gal}^{+}$ strains (Thomas and Crown, 1984). The difference between the 2 phenotypes seems to be due to a difference in galactokinase and/or galactose permease activity. Both enzymes are induced by galactose and repressed by lactose (Hutkins et al, $1985 a, b)$. Nucleotide sequences of the genes encoding the 2 constitutive enzymes are homologous with the analogous genes of other bacteria and yeasts. Their expression and regulation have been studied (Poolman et al, 1990). Until the present time, the use of galactose via the tagatose pathway has not been reported for either $S$ thermophilus or $L$ bulgaricus.

It is possible to obtain $\mathrm{Gal}^{+}$derivatives of $S$ thermophilus strains after growth of Gal- cultures in a chemostat under lactose limitation (Thomas and Crow, 1984). The use of $\mathrm{Gal}^{+}$strains in cheesemaking decreases residual galactose in Cheddar, Mozzarella, and Emmental cheeses and thus avoids some serious technological problems. As mentioned by Hutkins et al (1986), high residual galactose in cheese curd: (i) may enable a heterofermentative metabolism of galactose during ripening, with concomitant carbon dioxide production, and may also lead to the development of a harmful flora generating off-flavours and texture defects and (ii) has been implicated in browning reactions which occur during processing or cooking at high tem- 


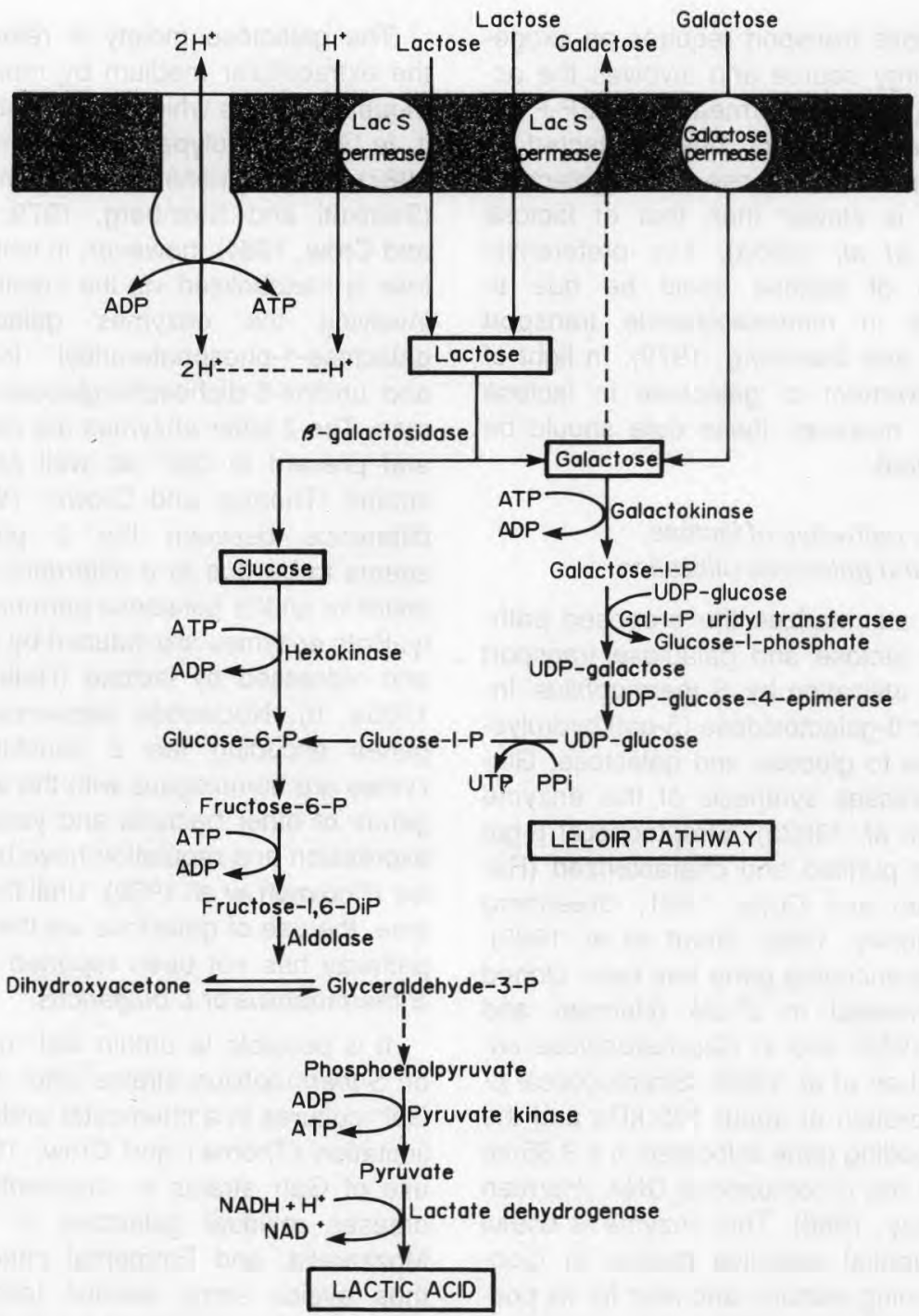

EMBDEN-MEYERHOF-PARNAS PATHWAY

Fig 1. Proposed pathways for lactose (lac) and galactose (gal) utilization in S thermophilus. From Hutkins and Morris (1987), Thompson (1987) and De Vos (1990). P: phosphate, PPi: inorganic pyrophosphate, ATP: adenosine triphosphate, ADP: adenosine diphosphate, UTP: uridine triphosphate, UDP: uridine diphosphate.

Voies métaboliques proposées pour l'utilisation du lactose (lac) et du galactose (gal) par S thermophilus. D'après Hutkins et Morris (1987), Thompson (1987) et De Vos (1990). P : phosphate, PPi : pyrophosphate inorganique, ATP : adénosine triphosphate, ADP : adénosine diphosphate, UTP : uridine triphosphate, UDP : uridine diphosphate. 
peratures of cheeses such as Cheddar or Mozzarella.

\section{Sucrose utilization}

Sucrose metabolism has been poorly documented, especially at the molecular and genetic levels. During the growth of $S$ thermophilus on sucrose, both glucose and fructose are used simultaneously. Fructose accumulates in the growth medium, however, even when the strain can use it (Thomas and Crow, 1983). The higher rate of sucrose utilization compared to those of glucose and fructose might be due to a different uptake rate (Hutkins and Morris, 1987).

An inhibitory effect of high sucrose content in milk $(10-12 \%)$, on the growth of yogurt bacteria has often been reported. It is due to both an adverse osmotic effect of the solutes in milk and a low water activity (Tamime and Robinson, 1985).

\section{Carbohydrate metabolism of $L$ bulgaricus}

$L$ bulgaricus is characterized by the utilization of a small number of carbohydrates, but their metabolism has not been studied enough. This lactobacillus uses only the glucose moiety of lactose and releases galactose into the growth medium. Some strains can use galactose in a growth medium containing limiting concentrations of lactose. Glucose transport occurs via a PTS-like system, while lactose and galactose uptake occurs by means of permeases (Hickey et al, 1986). Recent findings suggest that intracellular galactose is exchanged with lactose, enabling the transport of lactose as in $S$ thermophilus. In fact, preliminary results indicate that galactose efflux from the cells is stimulated almost 100 -fold by the presence of lactose in the external medium (Poolman et al, 1990). The lactose genes and gene organi- zation are well conserved in $S$ thermophilus and $L$ bulgaricus. Their lactose permeases and $\beta$-galactosidases share 60 and $48 \%$ common amino acids, respectively (Mercenier, 1990).

Once inside the cell, lactose is hydrolyzed by a $\beta$-gal. Glucose represses lactose transport and $\beta$-gal synthesis. Purified $\beta$-gal of an $L$ bulgaricus strain has a maximum activity at $50^{\circ} \mathrm{C}$ and $\mathrm{pH} 7$ (Itoh et al, $1980)$. The $\beta$-gal-encoding gene has been cloned in $E$ coli and expressed using its own promoter. The molecular mass of the enzyme is about $114 \mathrm{kDa}$, deduced from the nucleotide sequence of the corresponding gene (Schmidt et al, 1989). Galactose is metabolized by $L$ bulgaricus via the Leloir pathway. A galactokinase activity has been detected in Gal+ strains (Hickey et al, 1986).

\section{Lactic acid isomers in yogurt}

$S$ thermophilus possesses 2 FDPindependent L-LDH (Garvie, 1978; Hemme et $a l, 1981 \mathrm{a})$ and produces $\mathrm{L}(+)$ lactic acid, while $L$ bulgaricus produces $D(-)$ lactic acid and possesses an NAD-dependent stereospecific LDH (Gasser, 1970). Thus, both lactic acid isomers are simultaneously produced in yogurt.

The D-LDH of $L$ bulgaricus purified by Le Bras and Garel (1991) is a dimer composed of 2 identical $37-\mathrm{kDa}$ chains. The amino-terminal sequence determined on 50 residues is the first D-LDH sequence available and does not show significant homology with any known LDH. This suggests that the evolutionary process of DLDH from $L$ bulgaricus is not identical to that of the NAD-dependent L-LDH family.

$D(-)$ lactic acid is metabolized only very slowly in man compared to the $L(+)$ isomer and may cause metabolic disorders if ingested in excess. The World Health Organization therefore recommends a limited 
daily consumption of $\mathrm{D}(-)$ lactic acid to $100 \mathrm{mg} \cdot \mathrm{kg}^{-1}$ bodyweight and some countries, eg Germany, have decided to minimize the $D(-)$ lactic acid content of fermented dairy products (Kondratenko et al, 1989). In yogurt, this can only be obtained in the absence of $L$ bulgaricus producing the $D(-)$ isomer, which accounts for 30 $50 \%$ of the total lactic acid content of yogurt (Kunath and Kandler, 1980; Alm, 1982a). Nevertheless, the $D(-)$ lactic acid content may reach critical concentrations that can lead to disturbances especially when the diet is extremely unbalanced, but this finding has not yet been reported (Gurr, 1986). Rare cases of D(-)-lactic acidosis have been reported in children and adults, in association with altered bowel physiology (short gut syndrome) and proliferation of active D-lactate bacterial producers (Szylit and Nugon-Baudon, 1985).

Detection of a weak L-LDH activity in the type-strain of $L$ bulgaricus grown in a chemostat is therefore very interesting (Ragout et al, 1989). The identification of its mechanism of regulation could contribute to increase $L(+)$ lactic acid synthesis by this species and to reduce the $D(-)$ lactic acid content of yogurt.

\section{Formation of flavour compounds}

\section{Flavour compounds of yogurt}

The typical flavour of yogurt is due to lactic acid and various carbonyl compounds, ie acetaldehyde, acetone and diacetyl, produced by $S$ thermophilus and $L$ bulgaricus. In addition to carbonyl substances, many volatile compounds have also been identified in yogurt, ie volatile fatty acids (Turcic et al, 1969; Dumont and Adda, 1973) and several compounds derived from the thermal degradation of lipids, lactose and proteins during the heat treatment of milk be- fore yogurt manufacture eg aldehydes, ketones, alcohols, lactones, sulfur compounds (Tamime and Deeth, 1980).

Acetaldehyde is considered as the major flavour component of yogurt (Pette and Lolkema, 1950c; Dumont and Adda, 1973; Law, 1981) while high concentrations of this compound in other dairy products (cheese or cream) lead to flavour defects described as "green" or "yogurt-like" (Lindsay et al, 1965). Bottazzi and Vescovo (1969), however, underlined the importance of the acetaldehyde to acetone ratio.

Diacetyl contributes to the delicate, full flavour of yogurt and seems to be important when the acetaldehyde content is low (Groux, 1973a). According to Rasic and Kurmann (1978) $S$ thermophilus is the only microorganism responsible for diacetyl production in yogurt, whereas Dutta et al (1973) reported that diacetyl is also largely produced by $L$ bulgaricus (12-13 ppm for both species in pasteurized milk). Rysstad and Abrahamsen (1987) detected diacetyl in goat's milk yogurt with a low acetaldehyde content and suggested that diacetyl might be very important for the flavour of goat's milk yogurt.

Even though the importance of acetaldehyde, acetone and diacetyl for yogurt flavour is well established, it is very difficult to evaluate the contribution of several identified volatile compounds because their sensory perception thresholds vary considerably (Dumont and Adda, 1973).

In spite of important progress in chromatographic methods such as head-space techniques which increase the detection sensitivity of volatile compounds (DegorceDumas et al, 1986), only few recent studies are available in this field and none of them has involved a large number of strains examined using the recently developed techniques. Thus, it is difficult to compare results and conflicting findings 
may be due to the different sensitivity of the methods previously used.

\section{Metabolic pathways of acetaldehyde synthesis}

\section{Formation of acetaldehyde from glucose}

Two possible pathways exist:

- The Embden-Meyerhof-Parnas pathway generates pyruvate. An $\alpha$-carboxylase catalyzes the formation of acetaldehyde from pyruvate. An aldehyde dehydrogenase may also generate acetaldehyde from acetyl-CoA which is formed from pyruvate by the action of a pyruvate dehydrogenase. Neither significant $\alpha$-carboxylase nor aldehyde dehydrogenase activities have been detected by Raya et al (1986) in 2 strains of $S$ thermophilus and 2 strains of $L$ bulgaricus. Nevertheless, Lees and Jago (1976a) found an aldehyde dehydrogenase activity in 4 strains of each species. Therefore it is difficult to conclude whether this pathway occurs rarely or frequently in yogurt bacteria.

- The hexose monophosphate (HMP) pathway generates acetylphosphate. A phosphotransacetylase catalyzes the formation of acetyl-CoA from acetylphosphate and an acetate kinase leads to the formation of acetate. Although Raya et al (1986) detected these 2 activities in both yogurt bacteria, acetaldehyde cannot be formed by this pathway since their strains did not possess aldehyde dehydrogenase which catalyzes the biosynthesis of acetaldehyde from acetyl-CoA or acetate.

\section{Formation of acetaldehyde from threonine}

Threonine aldolase catalyzes the cleavage of threonine to acetaldehyde and glycine and appears to be the most important pathway for acetaldehyde production in yogurt. In fact, Raya et al (1986) detected this enzyme in 2 strains of $L$ bulgaricus, but not in the 2 strains of $S$ thermophilus investigated. In other studies, however, this enzyme was detected in both species (Lees and Jago, 1976b; Wilkins et al, 1986a; Marranzini et al, 1989). Streptococcal threonine aldolase activity decreases significaritly when growth temperature increases from 30 to $37^{\circ} \mathrm{C}$ (Lees and Jago, $1976 \mathrm{~b}$ ) or from 30 to $42{ }^{\circ} \mathrm{C}$ (Wilkins et al, $1986 \mathrm{~b})$, but that of $L$ bulgaricus remains almost identical. Thus, at 37 and $42^{\circ} \mathrm{C}$ threonine aldolase activity of the streptococci is significantly lower than that of the lactobacilli, whereas it is identical at $30^{\circ} \mathrm{C}$. Since yogurt is generally manufactured at high temperatures $\left(43^{\circ} \mathrm{C}\right)$, acetaldehyde is probably produced mainly by $L$ bulgaricus.

The addition of threonine $(0.6 \%)$ or glycine $(2 \%)$ to the growth medium does not significantly affect the specific activity of threonine aldolase in cell extracts (Lees and Jago, 1976b). High threonine concentrations combined with low glycine concentrations in the growth medium increase the biosynthesis of the enzyme. When this ratio is inverted, a decrease is observed. However, the threonine concentration during growth may have a greater effect on increasing threonine aldolase activity than the glycine concentration may have on inhibiting it. Streptococcal threonine aldolase is more affected by high glycine concentrations than the lactobacillus enzyme (Marranzini et al, 1989). The threonine aldolase of a $L$ bulgaricus strain has been partially purified and studied by Manca de Nadra et al (1987). Maximum enzyme activity is observed at $40{ }^{\circ} \mathrm{C}$ and $\mathrm{pH} 6.5$ as well as a strong allosteric $\mathrm{pH}$-dependent inhibition by glycine. Inhibition of threonine aldolase by glycine could explain the low acetaldehyde content of yogurt from goat's milk, which is richer in glycine than cow's milk (2.4 versus $0.84 \mathrm{mg} .100 \mathrm{ml}^{-1}$; Rysstad et al, 1990). 
Formation of acetaldehyde from DNA components

Two strains of $S$ thermophilus and one $L$ bulgaricus strain studied by Raya et al (1986) possess a deoxyriboaldolase which catalyzes the synthesis of acetaldehyde from 2-deoxyribose-5-phosphate. This enzyme could be involved in the degradation rather than the synthesis of DNA. The 4 lactobacilli strains and 3 out of the 4 streptococcal strains examined by Lees and Jago (1977) did not contain this enzyme.

\section{Alcohol dehydrogenase}

Alcohol dehydrogenase reduces acetaldehyde to ethanol. This enzyme has not been detected in $L$ bulgaricus but has been found in 2 of 4 strains of $S$ thermophilus (Lees and Jago, 1976a; Marshall and Cole, 1983; Raya et al, 1986).

\section{Production of polysaccharides}

Several Gram-negative and Gram-positive bacteria, including lactic acid bacteria, produce exocellular polysaccharides. The "ropy" character is often required for the manufacture of many fermented milk products. Ropy strains of lactococci have been isolated from Scandinavian fermented dairy products (Makura and Townsley, 1984; Nakajima et al, 1990). In stirred yogurt, yogurt beverages and low milk solids yogurts, production of polysaccharides can improve viscosity and texture, increase resistance to mechanical handling and decrease susceptibility to syneresis. The use of ropy strains is particularly important in France and in the Netherlands where the addition of stabilizers in yogurt is prohibited. In fact, some strains of $S$ thermophilus and $L$ bulgaricus produce neutral exopolysaccharides. Only few studies are available on the characterization and production of these polymers (Cerning, 1990).
Schellhaass (1983) isolated ropy strains of some thermophilic lactic acid bacteria. She observed higher exopolysaccharide production in milk at suboptimal growth temperatures, as measured by an increase of relative viscosity. The polymer material obtained contained galactose and glucose in the ratio 2:1. The slime secreted by a strain of $L$ bulgaricus studied by Groux (1973b) contained mainly galactose and some glucose, mannose and arabinose. Cerning et al (1988) studied an exocellular polysaccharide produced by $S$ thermophilus, which contains galactose $(55 \%)$, glucose $(25 \%)$, mannose $(15 \%)$ and small amounts of rhamnose, xylose and arabinose. The $L$ bulgaricus exopolysaccharide studied by Cerning et al (1986) contains galactose, glucose and rhamnose in an approximate molar ratio of $4: 1: 1$ with a molecular mass of about $500 \mathrm{kDa}$ and intrinsic viscosity of $4.7 \mathrm{dl} . \mathrm{g}^{-1}$. Doco et al (1990) studied an exopolysaccharide produced by $S$ thermophilus after $3-4 \mathrm{~h}$ of incubation and obtained a polymer composed of galactose, glucose and $\mathrm{N}$-acetylgalactosamine in a ratio of 2:1:1. The molecular mass of the polymer is $1 \times 10^{3} \mathrm{kDa}$ and intrinsic viscosity 1.54 dl. $g^{-1}$. Rhamnose, present mostly in the exopolysaccharides of $L$ bulgaricus, has not been identified in the exocellular polymer produced by 3 lactobacillus strains isolated from traditional Greek yogurts (Zourari, 1991). These molecules are composed of galactose $(50-70 \%)$, glucose $(20-40 \%)$ and some mannose and arabinose.

The quantities of polymer formed by ropy strains of both species vary considerably even under identical experimental conditions (Giraffa and Bergère, 1987; Cerning et al, 1990; Zourari, 1991), It is difficult to establish a good correlation between the quantity of polysaccharide produced and the corresponding viscosity. This difficulty may be due to changes in 
the 3-dimensional configuration of polymers and to their interactions with some milk compounds, mainly caseins that are precipitated at low $\mathrm{pH}$ (Olsen, 1989). In addition, viscosity measurements are difficult to interpret for non-Newtonian solutions such as milk and fermented milk products. Bottazzi and Bianchi (1986) studied by scanning electron microscopy (SEM) the structure of milk fermented with a ropy $L$ bulgaricus strain. It was shown that a part of the polysaccharide covers the cells with an uniform layer, and the rest of the polymer binds cells together and to milk casein via a dense network of visible filaments. Recently, Teggatz and Morris (1990) used SEM to explain changes occuring in the microstructure of ropy yogurt when it is subjected to a shear force. Their aim was to understand the interactions of exopolysaccharide material with its surroundings, and how they may influence viscosity. It was observed that an increase of shear rate first disrupts the attachment of polymer to the bacterial surface, but the polysaccharide material remains incorporated with the casein where it continues to influence viscosity.

The ropy character of $S$ thermophilus is often unstable (Cerning et al, 1988). This may be partially due to the presence of glycohydrolase enzymes capable of hydrolyzing the polysaccharide material. There is no evidence of a possible loss of plasmids encoding this character as in Lactococcus lactis subsp cremoris (Vedamuthu and $\mathrm{Ne}$ ville, 1986) or in Lactobacillus casei subsp casei (Vescovo et al, 1989). In fact, ropy strains of yogurt bacteria studied by Cerning et al $(1986,1988,1990)$ and Zourari (1991) are plasmid-free.

\section{OTHER METABOLIC ACTIVITIES}

\section{Proteolytic activity}

\section{Amino acids in milk and yogurt}

In yogurt, proteolysis is not determinant for organoleptic properties, but it is an important factor for the selection of strains for cheesemaking. On the other hand, proteolytic activity is greatly involved in both nutrition and interactions of yogurt bacteria, since lactic acid bacteria cannot synthesize essential amino acids. Therefore, they require an exogenous nitrogen source and utilize peptides and proteins in their growth medium by more or less complete enzyme systems.

$S$ thermophilus primarily requires glutamic acid, histidine and methionine, as well as cystine, valine, leucine, isoleucine, tryptophan, arginine and tyrosine for growth (Shankar and Davies, 1977; Bracquart et al, 1978). The uptake of branchedchain amino acids has been studied. It is an active transport which requires an exogenous energy source, depends on temperature and $\mathrm{pH}$ and is inhibited by L-cysteine (Akpemado and Bracquart, 1983).

The free amino acid content of cow's milk generally does not exceed $10 \mathrm{mg} \cdot 100$ $\mathrm{ml}^{-1}$ (Rasic and Kurmann, 1978; Miller et al, 1964; Alm; 1982c). In yogurt, the free amino acid pattern depends on the type of milk (animal species, season), its heat treatment, manufacturing techniques, bacterial strains used and storage conditions (Rasic et al, 1971a, b). The free amino acid content generally increases in yogurt compared to that of milk. $L$ bulgaricus ap- 
pears to be the main species responsible for these changes (Miller et al, 1964; Alm, 1982c; Feller et al, 1990).

\section{Utilization of proteins}

Milk proteins (caseins, whey proteins) are the main nitrogen source for lactic acid bacteria, which utilize them with the action of exocellular proteinases, membranebound aminopeptidases and intracellular exopeptidases and proteinases.

Proteinase activity has been detected in several strains of lactobacilli and streptococci by Ezzat et al (1985) and Kalantzopoulos et al (1990). L bulgaricus possesses a firmly cell-bound proteinase with optimum activity between 45 and $50^{\circ} \mathrm{C}$ and $\mathrm{pH}$ values ranging from 5.2 to 5.8 (Argyle et al, 1976). The partially purified cell-wall-associated proteinase studied by Ezzat et al (1987) has maximum activity at $35^{\circ} \mathrm{C}$ and $\mathrm{pH} 5.5$. The proteinase of $L$ bulgaricus is more active on $\beta$-casein than on whey proteins (Chandan et al, 1982). El Soda and Desmazeaud (1982) and Laloi (1989) revealed a preferential but partial hydrolysis of $\beta$ - and $\alpha_{s 1}$-caseins. Laloi (1989) also observed that after growth in milk, caseinolytic activity is 3 times higher than that measured after growth in a complex medium rich in short peptides.

Desmazeaud (1974) studied an intracellular metalloproteinase of $S$ thermophilus which was more active on the carboxymethylated B-chain of insulin or on glucagon than on caseins. A weak caseinolytic activity was detected in both the cell envelopes and cytoplasm of $S$ thermophilus. As the 2 corresponding enzymes had the same electrophoretic mobility they were considered to be identical (Meyer et al, 1989). A high cell-wall-associated proteinase activity characterizes 2 strains of $S$ thermophilus studied by Shahbal et al
(1991) who also obtained a proteinasenegative mutant. Strains which possess this proteolytic activity have a significantly higher acidification rate in milk compared with 13 other randomly chosen strains.

\section{Utilization of peptides}

The low molecular weight peptide fraction of milk is an important nitrogen source for yogurt bacteria. The importance of peptides for their growth stimulation and their acidification is now well established, especially for $S$ thermophilus (Desmazeaud and Devoyod, 1970; Desmazeaud and Hermier, 1973; Bracquart and Lorient, 1979; Hemme et al, 1981b).

$S$ thermophilus generally possesses a leucine-aminopeptidase activity (Bouillanne and Desmazeaud, 1980). Some strains possess an arginine-amino-peptidase activity which is usually inactive against dipeptides. Two intracellular metalloenzymes of this species have been purified and characterized, ie an amino-peptidase with broad specificity and a dipeptidase which hydrolyzes dipeptides with a hydrophobic and bulky residue at the $\mathrm{NH}_{2}$ terminal end (Rabier and Desma-zeaud, 1973). A non specific prolyl-dipeptidase hydrolyzing several dipeptides has also been detected (Desmazeaud and Jugé, 1976). An X-prolyl-dipeptidylamino-peptidase (Xpro-DPAP) of a $S$ thermophilus strain has been purified, characterized and compared with that of a $L$ bulgaricus strain. The streptococcal enzyme is composed of 2 subunits, has a molecular mass of 165 $\mathrm{kDa}$, an isoelectric point of 4.5 and optimum $\mathrm{pH}$ values ranging from 6.5 to 8.2 (Meyer and Jordi, 1987).

Two intracellular exopeptidases of $L$ bulgaricus have been characterized by $\mathrm{EI}$ Soda and Desmazeaud (1982), an aminopeptidase with specificity limited to argi- 
nine- $\beta$-naphthylamide, and a dipeptidase with broad specificity. Laloi (1989) revealed the presence of 4 aminopeptidases (API, II, III, IV) and an X-pro-DPAP in the same species. API and APIII (cytoplasmic enzymes) are induced after growth in a complex medium, while APII and APIV are constitutive. Mutants partially or totally free of APII or X-pro-DPAP have been isolated after chemical mutagenesis. Deficiency of these 2 enzymes significantly increases the caseinolytic activity of mutants compared to the parental strain (Atlan et al, 1989, 1990).

\section{Lipolytic activity}

Lipolysis is generally low in yogurt and is therefore not significant in terms of flavour. The free fatty acid content of yogurt differs only slightly from that of milk (Rasic and Vucurovic, 1973; Alm, 1982b). Therefore, only few studies with these enzyme systems have been reported in yogurt bacteria.

Tamime and Deeth (1980) have summarized the main lipolytic activities as follows: the hydrolytic activity of streptococci on tributyrin and triolein is high and, inversely, is low on milk fat and on Tween 40 or 60 . The hydrolytic activity of lactobacilli on tributyrin is weaker, while esterases hydrolyzing several soluble substrates, eg $\alpha$ naphthylacetate, are active in both bacteria.

$L$ bulgaricus possesses intracellular esterases active on ortho- and paranitrophenyl derivatives of short-chain fatty acids and activity levels vary only slightly between different strains ( $E I$ Soda et al, 1986). Many strains of $S$ thermophilus ( 30 out of 32 tested) possess a lipase more active towards tributyrin than towards natural lipids (De Moraes and Chandan, 1982) and maximum activity was observed at $45^{\circ} \mathrm{C}$ and $\mathrm{pH}$ 9. Kalantzopoulos et al
(1990) detected esterase- 1 and esterase-2 activities in both yogurt bacteria, using 2and 4-nitrophenylbutyrate, respectively.

\section{Urease activity}

In milk, $S$ thermophilus produces a large amount of carbon dioxide $\left(\mathrm{CO}_{2}\right)$ which is not formed from lactose metabolism since this microorganism is a strictly homofermentative species (Driessen et al, 1982). It also produces a large quantity of ammonia $\left(\mathrm{NH}_{3}\right)$ which was initially explained as resulting from the deamination of some amino acids (Groux, 1973a). $\mathrm{CO}_{2}$ production is due to the activity of urease, which breaks down milk urea (about $250 \mathrm{mg} . \mathrm{l}^{-1}$ ) into $\mathrm{CO}_{2}$ and $\mathrm{NH}_{3}$ (Miller and Kandler, 1967b; Tinson et al, 1982b; Juillard et al, 1988). This leads to the alkalinization of the growth medium and directly affects acidification rate measurements in milk (Spinnler and Corrieu, 1989; Famelart and Maubois, 1988; Zourari et al, 1991).

Urease activity is of technological interest for 3 reasons: (i) it enables streptococcal numbers in mixed cultures with $L$ bulgaricus (this lactobacillus has no urease activity) to be followed by measuring the amount of $\mathrm{CO}_{2}$ produced (Spinnler et al, 1987; Miller and Kandler, 1967a); (ii) $\mathrm{NH}_{3}$ production affects the evaluation of streptococcal acidifying properties by $\mathrm{pH}$ measurements; (iii) this activity may also be involved in the stimulation of lactobacilli by $\mathrm{CO}_{2}$ produced by the streptococci (see discussion below).

Besides its technological interest, the presence of urease activity in $S$ thermophilus also has taxonomic relevance. Although Farrow and Collins (1984) reported that $S$ thermophilus does not degrade urea, the presence of an urease activity seems to characterize most strains examined until now. It also characterizes oral 
S salivarius strains (Sissons et al, 1989) but lactococci do not possess this activity (Miller and Kandler, 1967b). The absence of urease activity in the 6 strains of $S$ thermophilus studied by Bridge and Sneath (1983) could be due to the prolonged incubation time $\left(5\right.$ days at $37^{\circ} \mathrm{C}$ ) before urease assays were carried out, since Juillard et al (1988) demonstrated that urease activity dropped during advanced stationary phase.

\section{Oxygen and metabolism}

Lactic acid bacteria are facultative anaerobes with a preference for anaerobic conditions (Whittenbury, 1978). They cannot synthesize porphyrins and consequently they do not synthesize cytochromes or catalase. Oxygen is sometimes used for the formation of hydrogen peroxide $\left(\mathrm{H}_{2} \mathrm{O}_{2}\right)$ which is toxic for lactic acid bacteria which do not contain catalase to break it down. Some species possess protection mechanisms, eg a high content of manganese which is oxidized by $\mathrm{O}_{2}^{-}$radicals in $\mathrm{Lac}$ tobacillus plantarum (Archibald and Fridovich, 1981).

$L$ bulgaricus is among the least oxygentolerant lactic acid bacteria (Archibald and Fridovich, 1981). It can produce a very large amount of $\mathrm{H}_{2} \mathrm{O}_{2}$ which activates the LPS system of milk (lactoperoxidasehydrogen peroxide-thiocyanate system) and inhibits its own growth as well as the growth of some other bacteria such as Lactobacillus acidophilus, associated in the manufacture of some fermented milk products (Gilliland and Speck, 1977). $S$ thermophilus does not produce enough $\mathrm{H}_{2} \mathrm{O}_{2}$ to activate the LPS system and therefore inhibition occurs only when exogenous $\mathrm{H}_{2} \mathrm{O}_{2}$ is added to milk (Premi and Bottazzi, 1972; Guirguis and Hickey, 1987). On the other hand, some strepto- coccal strains can degrade $\mathrm{H}_{2} \mathrm{O}_{2}$,eg strain TS2 studied by Smart and Thomas (1987). Nevertheless, no further experiments have been performed and the cleaving activity of this strain was attributed by the authors to a mechanism independent of active metabolism.

The differences generally observed between strains regarding their tolerance to and utilization of oxygen are due to variabilities in their enzymatic systems. Ritchey and Seeley (1976) detected no NADHoxidase activity in $3 \mathrm{~S}$ thermophilus strains, while many lactococcal strains possess this enzyme. Nevertheless, another well studied strain possesses this enzyme as well as NADH-peroxidase, superoxide dismutase, pyruvate and lactate dehydrogenases (Smart and Thomas, 1987).

Teraguchi et al (1987) compared the $S$ thermophilus STH 450 strain which has a high oxygen consumption, with the typestrain, ATCC 19258. Strain STH 450 has NADH-oxidase, but no pyruvate oxidase, and very low $\mathrm{NADH}$-peroxidase activity. These enzyme activities are much lower in the type-strain. Strain STH 450 accumulates $\alpha$-acetolactate, acetoin and diacetyl as end-products of aerobic glucose metabolism.

\section{PARTICULAR ASPECTS OF YOGURT FERMENTATION}

\section{Interactions between yogurt bacteria}

A positive interaction is generally observed between $S$ thermophilus and $L$ bulgaricus in mixed culture, leading to the stimulation of growth and acid production of both bacteria compared to their single-strain cultures (Pette and Lolkema, 1950a; Bautista et al, 1966; Accolas et al, 1977). In addi- 
tion, total proteolysis in mixed culture (expressed in $\mu \mathrm{g}$ of released tyrosine per $\mathrm{ml}$ of culture) exceeds the sum of the values obtained by each strain alone (Rajagopal and Sandine, 1990). Mixed yogurt cultures may also stimulate the production of some metabolites such as acetaldehyde (Hamdan et al, 1971; Bottazzi et al, 1973) and influence carbohydrate utilization. For instance, one $L$ bulgaricus strain studied which cannot use galactose in pure culture metabolizes this sugar when it is associated with one strain of $S$ thermophilus (Amoroso et al, 1988, 1989). Contrary behavior was observed with one streptococcal strain (Oner and Erickson, 1986) indicating that interactions between yogurt bacteria are very complex and are greatly dependent on the strains involved.

$S$ thermophilus does not possess substantial extracellular proteolytic activity and the amino acid and free peptide content of milk is not high enough to promote its full growth. Lactobacillus proteases break down caseins and supply the streptococcus with amino acids and peptides (Pette and Lolkema, 1950b, Bautista et al, 1966; Shankar and Davies, 1978; Radke-Mitchell and Sandine, 1984).

The growth of $L$ bulgaricus is stimulated by a compound produced by $S$ thermophilus, which seems to be formic acid (Galesloot et al, 1968; Veringa et al, 1968; Accolas et al, 1971; Shankar and Davies, 1978). Higashio et al (1978) reported a combined stimulating effect of formic and pyruvic acids. Suzuki et al (1986) observed that addition of formic acid to boiled milk prevents abnormal cell elongation in $L$ bulgaricus (filamentous forms). Formic acid synthesis from pyruvate is a limiting step in purine synthesis and this explains the combined action of the 2 acids. When formate is lacking, ribonucleic acid (RNA) synthesis is depressed. Elongated cells contain less RNA than normal cells while DNA contents of both cells are almost equal. The combined growth of $L$ bulgaricus and $S$ thermophilus has the same effect as the addition of formic acid. A better knowledge of pathways and kinetics of formic acid production by $S$ thermophilus is required to definitively establish the stimulating effect of this acid, questioned by Juillard et al (1987).

Driessen et al (1982) observed that stimulation of lactobacilli growth could also result from an increased $\mathrm{CO}_{2}$ content in the growth medium, during continuous culture at constant $\mathrm{pH}$. $S$ thermophilus produces a large quantity of $\mathrm{CO}_{2}$ from milk urea (Tinson et al, 1982b). In this way, it can stimulate lactobacilli, since the quantity of $\mathrm{CO}_{2}$ dissolved in milk decreases after heat treatment and so remaining $\mathrm{CO}_{2}$ is too low to meet the requirements of the lactobacillus (Driessen et al, 1982). Carbon dioxide might be involved in the synthesis of aspartic acid (Reiter and Oram, 1962).

In conclusion, interaction between yogurt bacteria is a good example of integrated metabolism in a mixed culture of lactic acid bacteria, but our knowledge on the stimulation of $L$ bulgaricus by $S$ thermophilus is still incomplete.

\section{Production of antimicrobial compounds by yogurt bacteria}

As mentioned above, there is generally a symbiotic relationship between yogurt bacteria, but growth inhibition is sometimes observed (Moon and Reinbold, 1974; Suzuki et al, 1982; Pereira Martins and Luchese, 1988). This should be taken into account when selecting starters. Inhibition may be due to competition for one or more nutrients of the growth medium (Moon and Reinbold, 1976) or to inhibitory compounds produced by the strains, such as bacteriocins and inhibitory peptides (Pereira Martins and Luchese, 1988). 
Pulusani et al (1979) extracted at least 3 fractions of $\approx 700 \mathrm{Da}$ from milk cultured with $S$ thermophilus, which inhibited the growth of Pseudomonas, Bacillus, E coli, Flavobacterium, Shigella, Salmonella and Lactococcus strains. These fractions are most likely aromatic amines released in the growth medium since cells are free of any antimicrobial activity. Glucose and lactose, but not sucrose, are essential for production of these compounds which are also obtained in milk-free media, eg "soymilk" (Rao and Pulusani, 1981).

Smaczny and Krämer (1984a) studied 2 bacteriocins of $10-20 \mathrm{kDa}$ produced by $2 S$ thermophilus strains which inhibited the growth of strains of the same species and to a lesser extent of enterobacteria. These molecules are sensitive to several proteases and to a lipase, suggesting that a lipid component participates in their active sites.

An antimicrobial substance named "bulgarican" produced by an L bulgaricus strain has been partially purified (Reddy and Shahani, 1971; Reddy et al, 1983). At neutral or acid $\mathrm{pH}$, this heat-stable substance was active against several strains of Bacillus, Streptococcus, Staphylococcus, Sarcina, Pseudomonas, Escherichia and Serratia species. Protonated carboxyl groups may be important for the activity of this molecule. Spillmann et al (1978) could not confirm, however, bulgarican production.

A newly isolated antibacterial substance from $L$ bulgaricus, active against a Pseudomonas fragi and a Staphylococcus aureus strains has optimum $\mathrm{pH}$ values close to 4. It is a di- or a tripeptide (molecular mass $<700 \mathrm{Da}$ ) which probably contains an aromatic group (Abdel-Bar et al, 1987).

Knowledge of antibacterial substances produced by yogurt bacteria is still fragmentary and the results are often contradictory. Available studies are few and give only little information on the nature of the compounds involved, their spectrum and mode of action. These antibacterial substances often seem to be peptides. More extensive study is required for a better understanding of interactions of yogurt bacteria with other lactic acid bacteria and with non-lactic cheese flora.

\section{Bacteriophages of L bulgaricus and $\mathrm{S}$ thermophilus}

Knowledge of the specific bacteriophages (phages) of thermophilic lactic acid bacteria has been well documented, primarily on and after 1980. Specific phages may attack $S$ thermophilus and $L$ bulgaricus strains during yogurt or cheese manufacture and seriously affect product quality. Moreover, even if phage attacks do not delay acidification during yogurt manufacture, they can lead to an important decrease in the streptococci and to a lower flavour score of the resulting yogurt (Stadhouders et al, 1988). Phage outbreaks are less frequent in modern yogurt production units than in cheese factories because: (a) the high heat treatment of milk destroys phages present in raw milk; (b) aseptic processing and packaging may prevent contaminations by airborne bacteriophages, bacteria, yeasts or moulds; and (c) according to Lawrence and Heap (1986), an increasing viscosity of the yogurt milk below $\mathrm{pH} 5.2$ and the fact that no whey is drained off during yogurt manufacture could efficiently reduce the spreading of phages in yogurt plants. Thus, phage attacks are due either to accidental contaminations (Stadhouders et al, 1984) or to the presence of lysogenic starter bacteria which might be the major source of phages by two possible routes: (i) and temperate phage particles derived from a lysogenic strain may infect a sensitive (indicator) strain of the same starter; 
(ii) temperate phages may give rise to virulent mutants able to superinfect and lyse the parental lysogenic and other related strains. A typical example of the latter incidence has been well documented for a lysogenic strain of Lactobacillus casei subsp casei used in Japan for the industrial manufacture of a fermented milk beverage, Yakult (Shimizu-Kadota and Sakurai, 1982; Shimizu-Kadota et al, 1985). Substitution of a prophage-free strain for the lysogenic strain immediately stopped all phage infections in the different Yakult production units.

Bacteriophages of $L$ bulgaricus are very closely related to those of $L$ delbrueckii subsp lactis ( $L$ lactis) but they are completely different from those of $L$ helveticus, which is usually used in cheesemaking (Séchaud, 1990). Two surveys of $L$ bulgaricus and $L$ lactis phages (Cluzel, 1986; Mata et al, 1986) led to the description of 4 groups named a, b, c and d. All these phages belong to the Siphoviridae family of Matthews (1982) which corresponds to Bradley's group B (Bradley, 1967). The head of these phages is isometric or prolate, collars are frequent, and the tails often have diverse terminal structures (pronged or plain plates, fibers) and occasionally harbour regularly spaced crossbars. Figures 2 and 3 illustrate some of these typical morphologies. Group $a$ is the largest phage group ( 20 of the 26 phages studied by Cluzel, 1986) and includes temperate phages of both subspecies ( 8 of the 20 phages of Cluzel's group a) along with lytic phages isolated in cheese plants or yogurt production units ( 12 of the 20 phages of Cluzel's group a). All phages of group a share common molecular characteristics, serological properties, lytic spectra and are specific towards both subspecies (typical morphology in figure 2). The close relationship between temperate and lytic phages of group a suggests that lysogeny may be

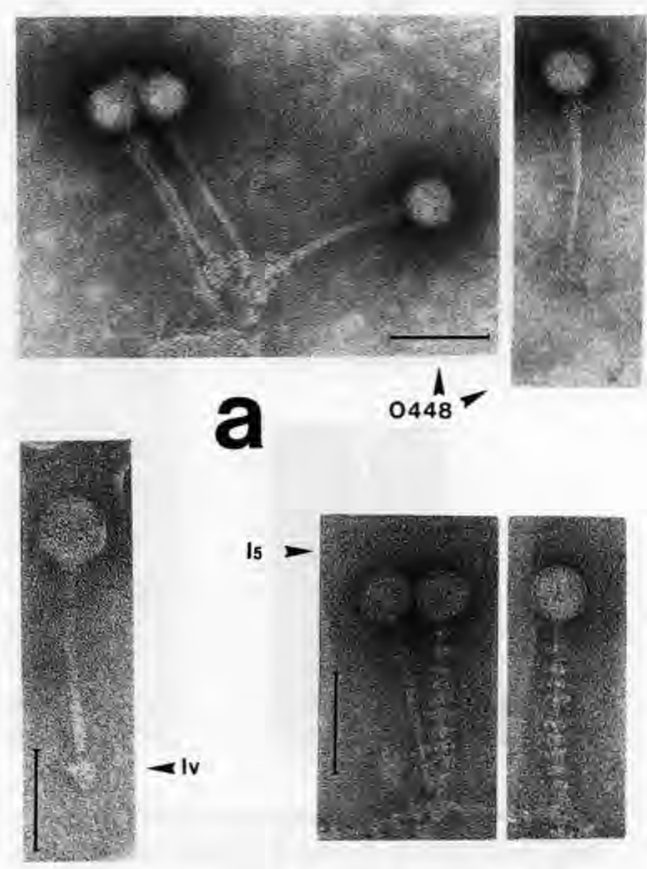

Fig 2. Morphology of bacteriophages which belong to group a. Their host-ranges include $L$ bulgaricus and $L$ lactis strains. Phage 15 possesses fragile cross-bars on its tail which may be easily removed during phage preparation. Collars are visible at the head-tail junctions of phage 0448 (triple collar) and phage Iv (single collar). Fibers are present at the tail tip of phages IV and 0448 . Bars $=100 \mathrm{~nm}$; the magnification factor is the same for all the pictures (micrographs from INRA, Jouy-en-Josas, France).

Morphologie de bactériophages du groupe a. Ces phages attaquent indifféremment un certain nombre de souches de $\mathrm{L}$ bulgaricus et $\mathrm{L}$ lactis. Le phage 15 possede des structures transversales fragiles tout le long de la queue, qui peuvent se détacher facilement au cours de la préparation du phage. Des colliers sont visibles à la jonction de la tête et de la queue des phages 0448 (triple collier) et Iv (collier simple). Des fibres sont présentes à l'extrémité distale de la queue des phages IV et 0448 . Barres $=100 \mathrm{~nm}$; l'agrandissement est le même pour toutes les images (micrographies de I'INRA, Jouy-enJosas, France). 

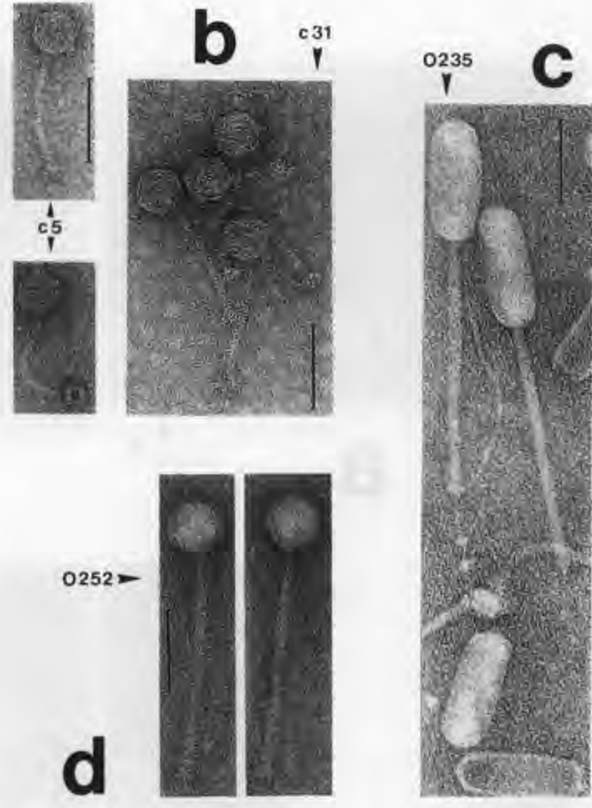

Fig 3. Morphology of bacteriophages which belong to groups b, $\mathbf{c}$ and $\mathbf{d}$. Phages of group $\mathbf{b}$, such as c31 and c5, have a host-range restricted to $L$ bulgaricus strains whereas phages 0235 (group c) and 0252 (group d) have hostranges similar to those of group a phages. Phages c 31 and $c 5$ (groupe b) possess a noncontractile tail fitted with a pronged base plate and at least one fiber. Tail tip of prolate-headed temperate phage 0235 (group c) exhibits a small base plate and a fiber with 2 swellings. Isometric-headed temperate phage 0252 (group d) possesses a fairly long tail with several fibers. Bars = $100 \mathrm{~nm}$; the magnification factor is the same for all the pictures (phages c31, 0235 and 0252: micrographs from INRA; phage c5: micrographs from INRA/ETH-Zürich).

Morphologie des phages des groupes $\boldsymbol{b}, \boldsymbol{c}$ et $\boldsymbol{d}$. Les phages du groupe $b$, tels que $c 31$ et $c 5$, ont un spectre d'hôtes limité à quelques souches de $\mathrm{L}$ bulgaricus, tandis que les phages 0235 (groupe c) et 0252 (groupe d) ont des spectres d'hôtes similaires à ceux des phages du groupe a. Les phages c31 et c5 (groupe b) possèdent une queue non contractile pourvue d'une plaque basale dentée et d'au moins une fibre. L'extrémité distale de la queue du phage tempéré à tête allongée 0235 (groupe c) porte une petite plaque basale et une fibre avec deux renflements. a determining factor in the occurrence and spread of these phages. Each of the groups $c$ and $d$ contains a single representative temperate phage of $L$ lactis. These 2 phages have lytic spectra similar to those of group a phages and consequently can infect some $L$ lactis as well as $L$ bulgaricus strains. However, no morphological (fig 3), molecular or serological similarities between them or with group a phages have been observed. Their low incidence may limit their importance in technology.

Group b is composed of 4 closely related virulent phages. They seem less widespread than group a phages and attack only $L$ bulgaricus strains. They have different lytic spectra and do not share molecular and serological relationships with phages of the 3 other groups. Some $L$ bulgaricus strains sensitive to group $b$ phages are lysogenic and harbour prophages that belong to group a. Prophagefree (cured) bacterial clones become sensitive to the corresponding temperate phage and to all other phages of groups a, $c$ and $d$ but are unexpectedly resistant to group b phages. Inversion of phage sensitivity occurs along with changes in morphology of bacterial colonies (rough form for cured clones/smooth form the parental lysogenic strains; Cluzel et al, 1987). This suggests that these strains could possess specific receptors for phages of all four groups. In the presence of prophage, only receptors for group b phages are functional while those for groups $a, c$ and d phages are masked or non-functional. It could be a lysogenic conversion.

Le phage à tête isométrique 0252 (groupe d) possède une queue assez longue, munie de plusieurs fibres terminales. Barres $=100 \mathrm{~nm}$; l'agrandissement est le même pour toutes les images (phages c31, 0235 et 0252 : micrographies de I'INRA; phage c5: micrographies de I'INRA / ETH-Zürich). 
The large number of group a phages underlines the risk resulting from the presence of lysogenic bacteria in lactic starters. Therefore, the use of cured strains appears to be a satisfactory solution, but requires strictly aseptic conditions during starter preparation and fermentation in order to prevent attacks by the widespread group a phages.

Among phages of $L$ bulgaricus and $L$ lactis, only phage $L L-H$, isolated in Finland and active against $L$ lactis strain $\mathrm{LL}$ 23, has been extensively studied (see Alatossava, 1987). Its morphology is representative of group a, and is closely related to that of phage Iv illustrated in figure 2 . The average burst size reaches $10^{2}$ phages per infected cell under optimal conditions. Phage LL-H contains 2 major structural proteins ( $34 \mathrm{kDa}$ for the head and 19 $\mathrm{kDa}$ for the tail) and no less than 5 minor proteins. The DNA molecules are linear (34 kbp) with constant ends. A restriction map of LL-H DNA has been established and a library of restriction fragments has been prepared by molecular cloning into $E$ coli. This had led to the localization of 5 genes encoding structural proteins and phage lysin. Phage LL-H DNA contains 2 polycistronic clusters of genes ie "early" genes which are involved in phage replication and "late" genes which encode structural proteins and phage lysin. Bivalent cations $\left(\mathrm{Ca}^{2+}\right.$ or $\left.\mathrm{Mg}^{2+}\right)$ stabilize the coiled DNA into the capsid, improve adsorption rate and control penetration efficiency of phage DNA into the bacterial cells. A molecular study of the LysA-encoding gene of $L$ bulgaricus temperate phage mv1 classified in group a (Boizet et al, 1990), revealed a close relationship between all lysins of group a phages (including $\mathrm{LL}-\mathrm{H}$ and mv1 enzymes). The lysA gene has a nucleotide sequence of 585 bp corresponding to a $21,120 \mathrm{Da}$ protein. Significant homology with the $\mathrm{N}$-terminal domain of known muramidases has been observed.
Recent studies in Germany and France have demonstrated the existence of an apparent homogeneity of the specific phages of $S$ thermophilus at both the morphological and molecular levels (Krush et al, 1987; Neve et al, 1989; Prévots et al, 1989; Benbadis et al, 1990; Larbi et al, 1990). These phages have been isolated as lytic and belong to the Siphoviridae family of Matthews (1982) or to Bradley's group B1 (Bradley, 1967), as shown in figure 4 . They contain linear double-stranded DNA (34-44 kb) with complementary cohesive ends. Grouping of these phages has been attempted on the basis of protein patterns and DNA restriction profiles. It is likely that most $S$ thermophilus phages studied until now were derived from a common ancestor. As indicated by Mercenier (1990), their genomes have non-homologous sequences flanked by homologous regions. It is consistent to apply the hypothesis of Botstein (1980) who postulated that the observed diversity of phages might result from recombination and exchange of "modules" ie genome fragments encoding for particular biological functions.

The existence of lysogenic strains in $S$ thermophilus has been reported several times since 1970 (Ciblis, 1970; Kurmann, 1979, 1983; Smaczny and Krämer, 1984b), but these studies remained incomplete. Neve et al (1990) detected prophages in 2 strains by probing chromosomal DNA of 17 strains with genomic DNA of virulent phages. Subsequently, the same authors demonstrated that these 2 strains were inducible by mitomycin C $(0.2-1$ $\mu \mathrm{g} \cdot \mathrm{ml}^{-1}$ ) and released mostly defective phage particles. However, these phages were able to relysogenize cured clones and formed turbid plaques on agar medium. Presence of prophage led to a modification of some phenotypic traits of the strains, ie homogeneous non-clumping cultures in broth instead of clumping in cured 
strains, and autolysis at $45^{\circ} \mathrm{C}$ probably due to the thermoinducibility of prophage at elevated temperature.

A survey of $S$ thermophilus phages is currently being carried out at the INRA laboratory at Jouy-en-Josas (B Fayard and M Haefliger, unpublished data). Ten of the 120 strains examined were shown to be lysogenic. Induction by mitomycin $\mathrm{C}$ gave temperate phages active on one or several indicator strains for 7 of them. Temperate phage DNA exhibited 5 different restriction patterns but shared homology. DNA homology also existed between temperate phages and 52 phages isolated as lytic following acidification failures. Preliminary results suggest that prophages might represent a phage source for $S$ thermophilus and the impact of lysogeny in current phage outbreaks should not be underestimated.

Starter suppliers and yogurt producers still lack basic information about the origin of disturbing phages and phage-bacteria relationships. This explains why they often adopt a pragmatic approach to the phage problem. Thus, an infected strain is replaced by an insensitive strain, sometimes by a spontaneously resistant mutant, with similar technological properties. This is the case for Australian yogurt manufacture (Hull, 1983). In day-to-day practice, phage control requires experience and "knowhown, but progress in the study of yogurt bacteria phages will certainly help to prevent phage attacks. For instance, improvement of phage resistance by genetic engineering might be the solution to phage problems in the future (Sanders, 1989).

\section{Genetics of S thermophilus and $\mathrm{L}$ bulgaricus}

Only few studies have been performed on the genetics of $S$ thermophilus, reviewed by Mercenier and Lemoine (1989) and Mercenier (1990). This is mainly due to important methodological problems, but also to the fact that the major functions are carried by chromosomal genes making studies more difficult. For this reason, many efforts have been made to adapt DNA transfer methods to this species. The organization and expression of genes involved in lactose and galactose metabolism were then studied by Herman and McKay (1986), Poolman et al (1989, 1990), and Lee et al (1990).

The plasmids of lactic acid bacteria encode important characters for dairy technology, eg carbohydrate metabolism, proteolytic activity, citrate utilization, production of antimicrobial compounds, bacteriophage and antibiotic resistance, polysaccharide production (McKay, 1983; Vedamuthu and Neville, 1986). S thermophilus and $L$ buigaricus seem to be naturally poor in plasmids (table I).

All plasmids mentioned in table I are considered as being cryptic. Most of the replicons isolated from $S$ thermophilus would be too small to carry a phenotypic trait (Mercenier, 1990). Until the present, the largest extrachromosomal element described is the 22.5-kb plasmid harboured by strain IP6631, along with 2 other small replicons (Gavoille, 1989).

Only one endogenous plasmid of $S$ thermophilus has been fully sequenced, ie plasmid pA33 $(6.9 \mathrm{~kb})$ from strain $\mathrm{AO} 33$ (Mercenier, 1990). Preliminary results indicate that this plasmid integrates and reexcises from chromosomal DNA. Its presence or absence as an autonomously replicating extrachromosomal element provides the host-cells with phenotypes which differ by their colony morphology, cell chain length, growth and acidification rates in milk, antibiotic resistance and phage sensitivity. The nucleotide sequence of this plasmid showed limited similarity with coding 


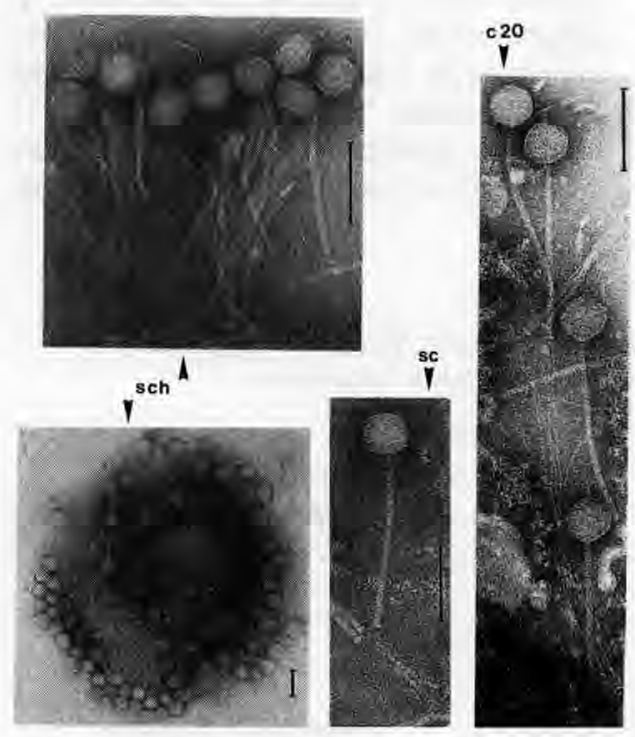

Fig 4. Morphology of $S$ thermophilus bacteriophages. All phages possess an isometric head and a fairly long and flexible tail, generally fitted with a small base plate. Tails of phage c20 exhibit a long fiber, whereas those of phages sch and SC are fitted with a shorter one. The cluster of phage sch particles adsorbed on a streptococcal cell debris is reminiscent of lysis from without. Bars $=100 \mathrm{~nm}$; the magnification factor is the same for all the pictures except phage cluster sch (micrographs from INRAVETH-Zürich).

Morphologie de bactériophages spécifiques de $\mathrm{S}$ thermophilus. Tous les phages possèdent une tête isométrique et une queue longue et flexible, généralement pourvue d'une petite plaque basale. La queue du phage c20 se prolonge par une longue fibre, tandis que celles des phages sch et sc sont munies d'une fibre plus courte. Le groupe de particules du phage sch adsorbées sur un débris cellulaire du streptocoque constitue une image évocatrice de la lyse externe. Barres $=100 \mathrm{~nm}$; l'agrandissement est le même pour toutes les images, à l'exception du groupe de particules du phage sch (micrographies de I'INRAVETH-Zürich).

sequences of some proteins of the outer membrane or of proteins involved in antibiotic resistance. This plasmid seems to be responsible for cell wall changes, but its role remains to be demonstrated. These observations should be considered in relation to specific chromosomal DNA rearrangements in $S$ thermophilus, which lead to morphologically different colonies (Pébay et al, 1989).

These general considerations also apply to $L$ bulgaricus. The rare plasmids are cryptic and genetic studies of different metabolic functions have just started. Morelli et al (1983) tried to correlate antibiotic resistance with the presence of plasmids in three lactobacillus strains. After treatment with curing agents (ethidium bromide, acriflavin) these strains lost several plasmids and their resistance to various antibiotics. However, the 2 observations cannot be correlated since the loss of plasmids and of antibiotic resistance was obtained by powerful mutagens which may also act on the chromosome.

\section{CONCLUSION}

Since 1980 many studies on $S$ thermophilus and $L$ bulgaricus have led to a better understanding of some metabolic and biochemical aspects of these bacteria that control their growth, especially in mixed cultures. For instance, lactose and galactose metabolism have been well studied at both the biochemical and molecular levels. In addition, some enzymes involved in the production of aroma compounds have been investigated. Production of exocellular polysaccharides by yogurt bacteria is now well established and some of these polymers have been studied. Several enzymes such as aminopeptidases, proteases, esterases and lipases have been characterized in both bacteria, especially proteases hydrolyzing caseins as well as urease activity of $S$ thermophilus because of their technological and taxonomical in- 
terest. The taxonomy of $S$ thermophilus is still debated and its definitive classification as an $S$ salivarius subspecies requires further consideration. Many bacteriophages of yogurt bacteria have been well characterized and their interactions with host- strains better established. In particular, lysogenic strains seem to be a major source of phages for $L$ bulgaricus and probably for $S$ thermophilus.

Many questions still remain unanswered. The molecular aspects of the me-

Table I. Distribution and characterization of plasmids from $S$ thermophilus and $L$ bulgaricus. Distribution et caractérisation de plasmides de $\mathrm{S}$ thermophilus et de L bulgaricus.

\begin{tabular}{|c|c|c|c|}
\hline Reference & $\begin{array}{l}\text { No of plasmids } \\
\text { per strain }\end{array}$ & $\begin{array}{l}\text { Plasmid size } \\
\text { (kb) }\end{array}$ & $\begin{array}{l}\text { Plasmid } \\
\text { characterization }\end{array}$ \\
\hline \multicolumn{4}{|l|}{$S$ thermophilus } \\
\hline Pechmann et al (1982) & $+(1 / 8)^{1}$ & - & - \\
\hline Herman and McKay (1985) & $1(5 / 23)$ & 2.1 to 3.3 & $\begin{array}{l}2 \text { plasmids in duplicate } \\
\text { (restriction profiles) } \\
\text { Homology of all plasmids } \\
\text { (DNA-DNA hybridization) }\end{array}$ \\
\hline $\begin{array}{l}\text { Somkuti and Steinberg } \\
\text { (1986a) }\end{array}$ & $\begin{array}{l}1(10 / 35) \\
2(3 / 35)\end{array}$ & 2.20 to 14.75 & $\begin{array}{l}9 \text { distinct types (restriction } \\
\text { profiles, obtained } \\
\text { using } 19 \text { endonucleases) }\end{array}$ \\
\hline Girard et al (1987) & $\begin{array}{l}1(6 / 50)^{2} \\
2(3 / 50)^{3}\end{array}$ & $2.9 \pm 0.1$ to $7.6 \pm 0.2$ & $\begin{array}{l}8 \text { types (size, restriction } \\
\text { profiles) - } 3 \text { groups } \\
\text { (DNA-DNA hybridization) }\end{array}$ \\
\hline L bulgaricus & & & \\
\hline Vescovo et al (1981) & $+(1 / 19)$ & - & s s s \\
\hline Klaenhammer et al (1979) & $+(1 / 1)$ & $52.5,40.5,13.5$ and 6 & - \\
\hline $\begin{array}{l}\text { Somkuti and Steinberg } \\
(1986 b)\end{array}$ & $4(1 / 1)$ & - & - \\
\hline Bosi et al (1990) & $\begin{array}{l}1(1 / 3) \\
2(2 / 3)\end{array}$ & 8.2 to 16.1 & - \\
\hline
\end{tabular}

+ : No of plasmids not given; - no data available. ${ }^{1}$ In parentheses, number of plasmid-containing strains on tested strains. ${ }^{2}$ Four strains isolated from raw milk and 2 industrial starter strains. ${ }^{3}$ Two strains isolated from raw milk and strain CNRZ 312.

+ : Le nombre de plasmides n'est pas donné. - Pas de données disponibles. ${ }^{1}$ Entre parenthèses, nombre de souches contenant des plasmides sur le nombre de souches testées. ${ }^{2}$ Quatre souches isolées du lait cru et deux souches provenant de levains industriels. ${ }^{3}$ Deux souches isolées du lait cru et la souche CNRZ 312. 
tabolism of sucrose and other carbohydrates should be better studied. This is particularly true for $L$ bulgaricus, since metabolic studies are less advanced than in $S$ thermophilus. Volatile compounds produced by $S$ thermophilus and $L$ bulgaricus remain to be identified because of their importance for the organoleptic properties of yogurt. The study of the different biosynthesis pathways of acetaldehyde and other volatile compounds, especially at the molecular level, is also necessary. Further research is needed in the field of exopolysaccharide production. In particular the genetics of the metabolic pathways (enzymes involved, and their regulation) require investigation in order to control and stabilize polysaccharide production in milk. The nutritional and possible therapeutic roles of these polymers remain to be confirmed.

In mixed cultures, the growth of $L$ bulgaricus and $S$ thermophilus is not yet fully controllable. Even if the interactions of these bacteria are well established, many aspects are still unknown. In particular, the real influence of associated growth on secondary metabolic activities has not been studied sufficiently. In addition, the characterization of inhibitory substances which may be produced would be very useful (a) for a better understanding of the relationship between the yogurt bacteria, and (b) for their action on other micro-organisms associated with yogurt bacteria for the manufacture of several fermented milk products.

Finally, progress in genetic studies should contribute to better knowledge on the yogurt bacteria and their growth and activity in milk.

\section{ACKNOWLEDGMENTS}

The authors are grateful to K Rérat (INRA, Service de Traduction UCD-CRJ, Jouy-en-Josas, France) who translated this paper into English and to $\mathrm{J}$ Cerning for helpful suggestions and discussions during preparation of the English version of this manuscript.

\section{REFERENCES}

Abdel-Bar N, Harris ND, Rill RL (1987) Purification and properties of an antimicrobial substance produced by Lactobacillus bulgaricus. J Food Sci 52, 411-415

Accolas JP, Veaux M, Auclair J (1971) Étude des interactions entre diverses bactéries lactiques thermophiles et mésophiles, en relation avec la fabrication des fromages à pâte cuite. Lait 51, 249-272

Accolas JP, Bloquel R, Didienne R, Régnier J (1977) Propriétés acidifiantes des bactéries lactiques thermophiles en relation avec la fabrication du yoghourt. Lait 57, 1-23

Akpemado KM, Bracquart PA (1983) Uptake of branched-chain amino acids by Streptococcus thermophilus. Appl Environ Microbiol 45, 136-140

Alatossava T (1987) Molecular biology of Lactobacillus lactis bacteriophage $\mathrm{LL}-\mathrm{H}$. Acta Univ Ouluensis Ser A 191, 1-65

Alm $L$ (1982a) Effect of fermentation on $L(+)$ and $\mathrm{D}(-)$ lactic acid in milk. $J$ Dairy Sci 65,515 520

Alm L (1982b) Effect of fermentation on milk fat of Swedish fermented milk products. J Dairy Sci $65,521-530$

Alm L (1982c) Effect of fermentation on proteins of Swedish fermented milk products. J Dairy Sci 65, 1696-1704

Amoroso MJ, Manca de Nadra MC, Oliver G (1988) Glucose, galactose, fructose, lactose and sucrose utilization by Lactobacillus bul- 
garicus and Streptococcus thermophilus isolated from commercial yoghurt. Milchwissenschaft 43, 626-631

Amoroso MJ, Manca de Nadra MC, Oliver G (1989) The growth and sugar utilization by Lactobacillus delbrueckii ssp bulgaricus and Streptococcus salivarius ssp thermophilus isolated from market yogurt. Lait 69, 519-528

Anonymous (1989) Technologie des yaourts et laits fermentés : les conséquences de la nouvelle réglementation. Tech Lait 1038, 22, 2526

Archibald FS, Fridovich I (1981) Manganese and defenses against oxygen toxicity in Lactobacillus plantarum. $J$ Bacteriol 145,442 451

Argyle PJ, Mathison GE, Chandan RC (1976) Production of cell-bound proteinase by Lactobacillus bulgaricus and its location in the bacterial cell. J Appl Bacteriol 41, 175-184

Atlan D, Laloi P, Portalier R (1989) Isolation and characterization of aminopeptidase-deficient Lactobacillus bulgaricus mutants. Appl Environ Microbiol 55, 1717-1723

Atlan D, Laloi P, Portalier R (1990) X-prolyldipeptidyl aminopeptidase of Lactobacillus delbrueckii subsp bulgaricus: characterization of the enzyme and isolation of deficient mutants. Appl Environ Microbiol 56, 21742179

Bautista ES, Dahiya RS, Speck ML (1966) Identification of compounds causing symbiotic growth of Streptococcus thermophilus and Lactobacillus bulgaricus in milk. J Dairy Res 33, 299-307

Béal C, Louvet P, Corrieu G (1989) Influence of controlled $\mathrm{pH}$ and temperature on the growth and acidification of pure cultures of Streptococcus thermophilus [CNRZ] 404 and Lactobacillus bulgaricus [CNRZ] 398. Appl Microbiol Biotechnol 32, 148-154

Benbadis L, Faelen M, Slos P, Fazel A, Mercenier A (1990) Characterization and comparison of virulent bacteriophages of Streptococcus thermophilus isolated from yogurt. Biochimie 72, 855-862

Boizet B, Lahbib-Mansais Y, Dupont L, Ritzenthaler P, Mata M (1990) Cloning, expression and sequence analysis of an endolysinencoding gene of Lactobacillus bulgaricus bacteriophage mv1. Gene 94, 61-67
Bosi F, Bottazzi V, Vescovo M, Scolari GL, Battistotti B, Dellaglio F (1990) Lactic acid bacteria for Grana cheese production. Part I: Technological characterization of thermophilic rod lactic acid bacteria. Sci Tecn Latt-Casearia 41, 105-136

Botstein D (1980) A theory of modular evolution for bacteriophages. Ann NY Acad Sci 354, 484-491

Bottazzi V, Vescovo M (1969) Carbonyl compounds produced by yYoghurt bacteria. Neth Milk Dairy J 23, 71-78

Bottazzi V, Bianchi F (1986) Types of microcolonies of lactic acid bacteria, formation of void spaces and polysaccharides in yoghurt. Sci Tecn Latt-Casearia 37, 297-315

Bottazzi V, Battistotti B, Montescani G (1973) Influence des souches seules et associées de $L$ bulgaricus et Str thermophilus ainsi que des traitements du lait sur la production d'aldehyde acétique dans le yaourt. Lait 53 , 295-308

Bouillanne C, Desmazeaud MJ (1980) Étude de quelques caractères de souches de Streptococcus thermophilus utilisées en fabrication de yoghourt et proposition d'une méthode de classement. Lait 60, 458-473

Bouillanne C, Desmazeaud MJ (1981) Classement de souches de Lactobacillus bulgaricus selon quelques caractères utilisés en fabrication du yoghourt. Association avec Streptococcus thermophilus. Sci Aliments 1, 7-17

Bracquart P, Lorient D (1979) Effet des acides aminés et peptides sur la croissance de Streptococcus thermophilus. III. Peptides comportant Glu, His et Met. Milchwissenschaft $34,676-679$

Bracquart P, Lorient D, Alais C (1978) Effet des acides aminés sur la croissance de Streptococcus thermophilus. II. Étude sur cinq souches. Milchwissenschaft 33, 341-344

Bradley DE (1967) A review: ultrastructure of bacteriophages and bacteriocins. Bacteriol Rev 33, 230-314

Bridge PD, Sneath PHA (1983) Numerical taxonomy of Streptococcus. J Gen Microbiol $129,565-597$

Cerning $J(1990)$ Exocellular polysaccharides produced by lactic acid bacteria. FEMS Microbiol Rev 87, 113-130 
Cerning J, Bouillanne C, Desmazeaud MJ, Landon M (1986) Isolation and characterization of exocellular polysaccharide produced by Lactobacillus bulgaricus. Biotechnol Lett 8, 625-628

Cerning J, Bouillanne C, Desmazeaud MJ, Landon M (1988) Exocellular polysaccharide production by Streptococcus thermophilus. Biotechnol Lett 10, 255-260

Cerning J, Bouillanne C, Landon M, Desmazeaud MJ (1990) Comparison of exocellular polysaccharide production by thermophilic lactic acid bacteria. Sci Aliments 10, 443-451

Chamba JF, Prost F (1989) Mesure de l'activité acidifiante des bactéries lactiques thermophiles utilisées pour la fabrication des fromages à pâte cuite. Lait 69, 417-431

Chandan RC, Argyle PJ, Mathison GE (1982) Action of Lactobacillus bulgaricus proteinase preparations on milk proteins. J Dairy Sci 65, 1408-1413

Ciblis E (1970) Characterization of a bacteriophage of Streptococcus thermophilus. Zentralbl Bakteriol Parasitenkd Infektionskr Hyg 2 Abt 125, 541-554

Cluzel PJ (1986) Classification de 26 bactériophages de Lactobacillus bulgaricus et de Lactobacillus lactis. Thèse DocteurIngénieur, INA-PG, Paris, France

Cluzel PJ, Sério J, Accolas JP (1987) Interactions of Lactobacillus bulgaricus temperate bacteriophage 0448 with host strains. Appl Environ Microbiol 53, 1850-1854

Colmin C, Pébay M, Simonet JM, Decaris B (1991) A species-specific DNA probe of Streptococcus salivarius subsp thermophilus detects strain restriction polymorphism. FEMS Microbiol Lett 81, 123-128

Corrieu G, Spinnler HE, Picque D, Jomier $Y$ (1989) Procédé de mise en évidence et de contrôle de l'activité acidifiante d'agents de fermentation dans des bains de fermentation et dispositif pour sa mise en œuvre. Pat $\mathrm{Fr}$ No 2629612, 6.10.1989

Deeth HC, Tamime AY (1981) Yogurt: nutritive and therapeutic aspects. J Food Prot 44, 7886

Degorce-Dumas R, Goursaud J, Leveau JY (1986) Analyse de composés volatils du yaourt par chromatographie en phase ga- zeuse-espace de tête (headspace). Ind AgroAlimentaires 8, 805-808

Dellaglio F, Bottazzi V, Trovatelli LD (1973) Deoxyribonucleic acid homology and base composition in some thermophilic lactobacilli. J Gen Microbiol 74, 289-297

Delley M, Mollet B, Hottinger H (1990) DNA probe for Lactobacillus delbrueckii. Appl Environ Microbiol 56, 1967-1970

De Moraes J, Chandan RC (1982) Factors influencing the production and activity of a Streptococcus thermophilus lipase. J Food Sci 47, 1579-1583

Desmazeaud MJ (1974) Propriétés générales et spécificité d'action d'une endopeptidase neutre intracellulaire de Streptococcus thermophilus. Biochimie 56, 1173-1181

Desmazeaud MJ, Devoyod JJ (1970) Action stimulante des microcoques caséolytiques sur les bactéries lactiques thermophiles. Mise en évidence de la nature peptidique des substances stimulantes. Ann Biol Anim Biochim Biophys 10, 413-430

Desmazeaud MJ, Hermier JH (1973) Effet de fragments peptidiques du glucagon vis-à-vis de la croissance de Streptococcus thermophilus. Biochimie 55, 679-684

Desmazeaud MJ, Jugé M (1976) Caractérisation de l'activité protéolytique et fractionnement des dipeptidases et des aminopeptidases de Streptococcus thermophilus. Lait 56, 241-260

De Vos WM (1990) Disaccharide utilization in lactic acid bacteria. In: 6 th Int Symp on Genetics of Industrial Microorganisms Proc, Vol I. Soc Fr Microbiologie, 447-457

Doco $T$, Wièruszeski JM, Fournet $B$, Carcano $D$, Ramos P, Loones A (1990) Structure of an exocellular polysaccharide produced by Streptococcus thermophilus. Carbohydr Res 198, 313-322

Driessen FM, Kingma F, Stadhouders J (1982) Evidence that Lactobacillus bulgaricus in yogurt is stimulated by carbon dioxide produced by Streptococcus thermophilus. Neth Milk Dairy J 36, 135-144

Dumont JP, Adda J (1973) Méthode rapide [d'étude] des composés très volatils de l'arôme des produits laitiers. Application au yoghourt. Lait 53, 12-22 
Dutta SM, Kuila RK, Ranganathan B (1973) Effect of different heat treatments of milk on acid and flavour production by five single strain cultures. Milchwissenschaft 28, 231233

El Soda M, Desmazeaud MJ (1982) Les peptide-hydrolases des lactobacilles du groupe Thermobacterium. I. Mise en évidence de ces activités chez Lactobacillus helveticus, $L$ acidophilus, $L$ lactis et $L$ bulgaricus. Can $J$ Microbiol 28, 1181-1188

El Soda M, Abd El Wahab H, Ezzat N, Desmazeaud MJ, Ismail A (1986) The esterolytic and lipolytic activities of the lactobacilli. II. Detection of the esterase system of Lactoba. cillus helveticus, Lactobacillus bulgaricus, Lactobacillus lactis and Lactobacillus acidophilus. Lait 66, 431-443

Ezzat N, El Soda M, Bouillanne C, Zevaco C, Blanchard P (1985) Cell wall associated proteinases in Lactobacillus helveticus, Lactobacillus bulgaricus and Lactobacillus lactis. Milchwissenschaft 40, 140-143

Ezzat N, Zevaco C, El Soda M, Gripon JC (1987) Partial purification and characterization of a cell wall associated proteinase from Lactobacillus bulgaricus. Milchwissenchaft 42, 95-97

Famelart MH, Maubois JL (1988) Comparaison de l'évolution de l'indice de réfraction et de la viscosité au cours de la gélification lactique du lait. Lait $68,1-12$

Farrow JAE, Collins MD (1984) DNA base composition, DNA-DNA homology and longchain fatty acid studies on Streptococcus thermophilus and Streptococcus salivarius. J Gen Microbiol 130, 357-362

Feller E, Cescatti G, Seppi A, Avancini A, Giacomelli F, Bossi MG (1990) Yoghurt. Nutritional, microbiological and biochemical characteristics. Latte 15, 674-683

Fox PF (1989) The milk protein system. In: Developments in Dairy Chemistry - 4. Functional Milk Proteins (Fox PF, ed) Elsevier Appl Sci, London, 1-53

Galesloot TE, Hassing F, Veringa HA (1968) Symbiosis in yoghurt (I). Stimulation of Lactobacillus bulgaricus by a factor produced by Streptococcus thermophilus. Neth Milk Dairy $\mathrm{J} 22,50-63$
Garvie El (1978) Lactate dehydrogenases of Streptococcus thermophilus. J Dairy Res 45, 515-518

Garvie El, Farrow JAE (1981) Sub-divisions within the genus Streptococcus using deoxyribonucleic acid / ribosomal ribonucleic acid hybridization. Zentralbl Bakteriol Mikrobiol Hyg 1 Abt Orig C 2, 299-310

Gasser F (1970) Electrophoretic characterization of lactic dehydrogenases in the genus Lactobacillus. J Gen Microbiol 62, 223-239

Gavoille S (1989) Analyse et caractérisation de I'ADN plasmidique de Streptococcus salivarius subsp thermophilus souche IP6631. Mémoire DEA, Univ Nancy I, France

Gilliland SE, Speck ML (1977) Instability of Lactobacillus acidophilus in yogurt. $J$ Dairy $\mathrm{Sci}$ $60,1394-1398$

Girafía G, Bergère JL (1987) Nature du caractère épaississant de certaines souches de Streptococcus thermophilus: étude préliminaire. Lait 67, 285-298

Girard F, Lautier M, Novel G (1987) DNA-DNA homology between plasmids from Streptococcus thermophilus. Lait 67, 537-544

Greenberg NA, Mahoney RR (1982) Production and characterization of $\beta$-galactosidase from Streptococcus thermophilus. J Food Sci 47, 1824-1828, 1835

Groux M (1973a) Étude des composants de la flaveur du yoghourt. Lait 53, 146-153

Groux M (1973b) Kritische Betrachtung des heutigen Joghurt-Herstellung mit Berücksichtung des Protein-Abbaues. Schweiz Milchzig 4, 2-8

Guirguis N, Hickey MW (1987) Factors affecting the performance of thermophilic starters. 2 . Sensitivity to the lactoperoxidase system. Aust J Dairy Technol 42, 14-16

Gurr MI (1986) Nutritional aspects of fermented milk products. In: 22th Int Dairy Congr $\mathrm{E}$, T Le Hague, 641-655

Hamdam IY, Kunsman JE Jr, Deane DD (1971) Acetaldehyde production by combined yogurt cultures. J Dairy Sci 54, 1080-1082

Hardie JM (1986) Genus Streptocccus. In: Bergey's Manual of Systematic Bacteriology, Vol 2 (Sneath PHA, Mair NS, Sharpe ME, Holt JG, eds) Williams \& Wilkins, Baltimore, 10431070 
Hemme D, Nardi M, Wahl D (1981a) Propriétés des lacticodéshydrogénases de Streptococcus thermophilus indépendantes du fructose 1,6-diphosphate. Lait 61, 1-18

Hemme DH, Schmal V, Auclair JE (1981b) Effect of the addition of extracts of thermophilic lactobacilli on acid production by Streptococcus thermophilus in milk. J Dairy Res 48 , 139-148

Herman RE, McKay LL (1985) Isolation and partial characterization of plasmid DNA from Streptococcus thermophilus. Appl Environ Microbiol 50, 1103-1106

Herman RE, McKay LL (1986) Cloning and expression of the $\beta$-D-galactosidase gene from Streptococcus thermophilus in Escherichia coli. Appl Environ Microbiol 52, 45-50

Hickey MW, Hillier AJ, Jago GR (1986) Transport and metabolism of lactose, glucose and galactose in homofermentative lactobacilli. Appl Environ Microbiol 51, 825-831

Higashio K, Kikuchi T, Furuichi E (1978) Symbiose entre Lactobacillus bulgaricus et Streptococcus thermophilus dans le yoghourt. 20th Congr Int Lait F, 522-523

Hull RR (1983) Factory-derived starter cultures for the control of bacteriophage in cheese manufacture. Aust J Dairy Technol 38, 149154

Hutkins R, Morris HA, McKay LL (1985a) Galactose transport in Streptococcus thermophilus. Appl Environ Microbiol 50, $772-776$

Hutkins R, Morris HA, McKay LL (1985b) Galactokinase activity in Streptococcus thermophilus. Appl Environ Microbiol 50, 777-780

Hutkins R, Halambeck SM, Morris HA (1986) Use of galactose-fermenting Streptococcus thermophilus in the manufacture of Swiss, Mozzarella and short-method Cheddar cheese. J Dairy Sci 69, 1-8

Hutkins RW, Morris HA (1987) Carbohydrate metabolism by Streptococcus thermophilus: a review. J Food Prot 50, 876-884

Hutkins RW, Ponne C (1991) Lactose uptake driven by galactose efflux in Streptococcus thermophilus: evidence for a galactoselactose antiporter. Appl Environ Microbiol 57. 941-944

Itoh T, Ohhashi M, Toba T, Adachi S (1980) Purification and properties of $\beta$-galactosidase from Lactobacillus bulgaricus. Milchwissenschaft 35, 593-597

Juillard V, Spinnler HE, Desmazeaud MJ, Boquien CY (1987) Phénomènes de coopération et d'inhibition entre les bactéries lactiques utilisées en industrie laitière. Lait 67, 149-172

Juillard V, Desmazeaud MJ, Spinnler HE (1988) Mise en évidence d'une activité uréasique chez Streptococcus thermophilus. Can J Microbiol 34, 818-822

Kalantzopoulos G, Tsakalidou E, Manolopoulou E (1990) Proteinase, peptidase and esterase activities of cell-free extracts from wild strains of Lactobacillus delbrueckii subsp bulgaricus and Streptococcus salivarius subsp thermophilus isolated from Greek yogurt. J Dairy Res 57, 593-601

Kandler O, Weiss N (1986) Genus Lactobacillus. In: Bergey's Manual of Systematic Bacteriology, Vol 2 (Sneath PHA, Mair NS, Sharpe ME, Holt JG, eds) Williams and Wilkins, Baltimore, MD 1209-1234

Kilpper-Bälz R, Fischer G, Schleifer KH (1982) Nucleic acid hybridization of Group $\mathrm{N}$ and Group D streptococci. Curr Microbiol 7, 245250

Klaenhammer TR, Scott LF, Sutherland SM, Speck ML (1979) Plasmid DNA isolation from Lactobacillus acidophilus and Lactobacillus bulgaricus. Abstr Annu Meet Am Soc Microbiol 79, 132 (Dairy Sci Abstr 42, 1677)

Kondratenko MS, Saeva SS, Iwanova PD, Bankova N (1989) Neue Säurewecker für bulgarische Sauermilch. Dtsch Molk-Ztg 31, 978980

Krusch U, Neve H, Luschei B, Teuber M (1987) Characterization of virulent bacteriophages of Streptococcus salivarius subsp thermophilus by host specificity and electron microscopy. Kiel Milchwirtsch Forschungsber 39, 155-167

Kunath P, Kandler O (1980) Der Gehalt an L(+)und $D(-)$-Milchsäure in Joghurtprodukten. Milchwissenschaft 35, 470-473

Kurmann JA (1984) Aspects of the production of fermented milks. Bull Fed Int Lait 179, 16-28

Kurmann JL (1979) Bakteriophagenbedingte Säuerungsstörungen in Hartkäsereine. Schweiz Milchwirtsch Forsch 8, 71-76

Kurmann JL (1983) Freisetzen von Bakteriophagen bei thermophilen Milchsäurebakterien 
durch Penicillin, eine verbogene Ursache für phagenbedingte Säuerungsstörungen. Schweiz Milchwirtsch Forsch 12, 39-43

Laloi P (1989) Analyse biochimique, physiologique et génétique de l'activité caséinolytique et des aminopeptidases de LactobacilIus bulgaricus. Thèse Doctorat, Univ Lyon I, France

Larbi D, Colmin C, Rousselle L, Decaris B, Simonet JM (1990) Genetic and biological characterization of nine Streptococcus salivarius subsp thermophilus bacteriophages. Lait 70, 107-116

Law BA (1981) The formation of aroma and flavour compounds in fermented dairy products. Dairy Sci Abstr 43, 143-154

Lawrence RC, Heap HA (1986) The New Zealand starter system. Bull Fed Int Lait 199, 1420

Le Bras G, Garel JR (1991) Properties of Dlactate dehydrogenase from Lactobacillus bulgaricus: a possible different evolutionary origin for the $\mathrm{D}$ - and L-lactate dehydrogenases. FEMS Microbiol Lett 79, 89-94

Lee BH, Robert N, Jacques C, Ricard L (1990) Cloning and expression of $\beta$-galactosidase gene from Streptococcus thermophilus in Saccharomyces cerevisiae. Biotechnol Lett 12, 499-504

Lees GJ, Jago GR (1976a) Acetaldehyde: an intermediate in the formation of ethanol from glucose by lactic acid bacteria. J Dairy Res $43,63-73$

Lees GJ, Jago GR (1976b) Formation of acetaldehyde from threonine by lactic acid bacteria. J Dairy Res 43, 75-83

Lees GJ, Jago GR (1977) Formation of acetaldehyde from 2-deoxy-D-ribose-5-phosphate in lactic acid bacteria. $J$ Dairy Res 44, 139144

Lindsay RC, Day EA, Sandine WE (1965) Green flavour defect in lactic starter cultures. J Dairy Sci 48, 863-869

London J, Kline K (1973) Aldolase of lactic acid bacteria: a case history in the use of an enzyme as an evolutionary marker. Bacteriol Rev 37, 453-478

Macura D, Townsley PM (1984) Scandinavian ropy milk-Identification and characterization of endogenous ropy lactic streptococci and their extracellular excretion. J Dairy Sci 67 , 735-744

Manca de Nadra MC, Raya RR, Pesce de Ruiz Holgado A, Olivier G (1987) Isolation and properties of threonine aldolase of Lactobacillus bulgaricus YOP12. Milchwissenschaft $42,92-94$

Marranzini RM, Schmidt RH, Shireman RB, Marshall MR, Cornell JA (1989) Effect of threonine and glycine concentrations on threonine aldolase activity of yogurt microorganisms during growth in modified milk prepared by ultrafiltration. J Dairy Sci 72, 1142-1148

Marshall VM, Cole WM (1983) Threonine aldolase and alcohol dehydrogenase activities in Lactobacillus bulgaricus and Lactobacillus acidophilus and their contribution to flavour production in fermented milks. I Dairy Res $50,375-379$

Mata M, Trautwetter A, Luthaud G, Ritzenthaler $P$ (1986) Thirteen virulent and temperate bacteriophages of Lactobacillus bulgaricus and Lactobacillus lactis belong to a single DNA homology group. Appl Environ Microbiol $52,812-818$

Matthews REF (1982) Classification and nomenclature of viruses. Fourth report of the International Committee on Taxonomy of Viruses. Intervirology 17, 1-200

McKay LL (1983) Functional properties of plasmids in lactic streptococci. Antonie van Leeuwenhoek 49, 259-274

Mercenier A (1990) Molecular genetics of Streptococcus thermophilus. FEMS Microbiol Rev $87,61-78$

Mercenier A, Lemoine $Y$ (1989) Genetics of Streptococcus thermophilus: a review. J Dairy Sci 72, 3444-3454

Meyer J, Jordi R (1987) Purification and characterization of X-prolyl-dipeptidyl-aminopeptidase from Lactobacillus lactis and from Streptococcus thermophilus. J Dairy Sci 70, 738-745

Meyer J, Howald D, Jordi R, Fürst M (1989) Location of proteolytic enzymes in Lactobacillus lactis and Streptococcus thermophilus and their influence on cheese ripening. Milchwissenschaft 44, 678-681 
Miller I, Kandler O (1967a) Eiweißabbau und Anreicherung freier Aminosäueren durch Milchsäurebakterien in Milch. I. Die Veränderung des Stickstoff-Fraktionen. Milchwissenschaft 22, 150-159

Miller I, Kandler O (1967b) Eiweißabbau und Anreicherung freier Aminosäueren durch Milchsäurebakterien in Milch. III. Die Anreicherung von freien Aminosäuren durch Streptobakterien und Streptokokken. Milchwissenschaft 22, 608-615

Miller I, Martin H, Kandler O (1964) Das Aminosäurespektrum von Joghurt. Milchwissenschaft 19, 18-25

Moon NJ, Reinbold GW (1974) Selection of active and compatible starters for yogurt. Cult Dairy Prod J 9, $10 \& 12$

Moon NJ, Reinbold GW (1976) Commensalism and competition in mixed cultures of Lactobacillus bulgaricus and Streptococcus thermophilus. J Milk Food Technol 39, 337-341

Morelli L, Vescovo M, Bottazzi V (1983) Plasmids and antibiotic resistances in Lactobacillus helveticus and Lactobacillus bulgaricus isolated from natural whey cultures. Microbiologica 6, 145-154

Nakajima $H$, Toyoda S, Toba $T$, Itoh $T$, Mukai $T$, Kitazawa H, Adachi S (1990) A novel phosphopolysaccharide from slime-forming Lactococcus lactis subsp cremoris SBT 0495. J Dairy Sci 73, 1472-1477

Neve H, Krusch U, Teuber M (1989) Classification of virulent bacteriophages of Streptococcus salivarius subsp thermophilus isolated from yoghurt and Swiss-type cheese. Appl Microbiol Biotechnol 30, 624-629

Neve H, Krusch U, Teuber M (1990) Virulent and temperate bacteriophages of thermophilic lactic acid streptococci. 23th Congr Int Lait, Vol II, 363

Olsen RL (1989) Effects of polysaccharides on rennet coagulation of skim milk proteins. J Dairy Sci 72, 1695-1700

Oner MD, Erickson LE (1986) Anaerobic fermentation of Lactobacillus bulgaricus and Streptococcus thermophilus on $3 \%$ non-fat dry milk with pure and mixed culture. Biotechnol Bioeng 28, 883-894

Orla-Jensen S (1919) The Lactic Acid Bacteria. AF Host and Son, eds, Copenhagen
Pébay M, Colmin C, Decaris B, Simonet JM (1989) Variations phénotypiques et réarrangements génomiques chez Streptococcus thermophilus. 2nd Congr Soc Fr Microbiol, 127

Pechmann H, Geis A, Teuber M (1982) Plasmides des streptocoques lactiques. 21st Congr Int Lait F, vol 1, book 2, 352-353

Pereira Martins JF, Luchese RH (1988) The assessment of growth compatibility between strains of Lactobacillus bulgaricus and Streptococcus thermophilus. Rev Inst Latic Cândido Tostes (Brasil) 43, 11-13

Pette JW, Lolkema H (1950a) Yoghurt. I. Symbiosis and antibiosis in mixed cultures of $L b$ bulgaricus and Se thermophilus. Neth Milk Dairy J 4, 197-208

Pette JW, Lolkema H (1950b) Yoghurt. II. Growth stimulating factors for Sc thermophiIus. Neth Milk Dairy J 4, 209-224

Pette JW, Lolkema H (1950c) Yoghurt. III. Acid production and aroma formation in yoghurt. Neth Milk Dairy J 4, 261-273

Poolman B, Royer TJ, Mainzer SE, Schmidt BF (1989) Lactose transport system of Streptococcus thermophilus: a hybrid protein with homology to the melibiose carrier and enzyme III of phosphoenolpyruvate-dependent phosphotransferase systems. J Bacteriol $171,244-253$

Poolman B, Royer TJ, Mainzer SE, Schmidt BF (1990) Carbohydrate utilization in Streptococcus thermophilus: characterization of the genes for aldolase 1-epimerase (mutarotase) and UDPglucose 4-epimerase. J Bacteriol $172,4037-4047$

Premi L, Bottazzi V (1972) Hydrogen peroxide formation and hydrogen peroxide splitting activity in lactic acid bacteria. Milchwissenschaft 27, 762-765

Prevots F, Relano P, Mata M, Ritzenthaler P (1989) Close relationship of virulent bacteriophages of Streptococcus salivarius subsp thermophilus at both the protein and the DNA levels. J Gen Microbiol 135, 3337-3344

Puhan Z (1988) Results of the questionnaire 1785B "Fermented milks". Bull Fed Int Lait 227, 138-164

Pulusani SR, Rao DR, Sunki GR (1979) Antimicrobial activity of lactic cultures: partial purifi- 
cation and characterization of antimicrobial compound(s) produced by Streptococcus thermophilus. J Food Sci 44, 575-578

Rabier D, Desmazeaud MJ (1973) Inventaire des différentes activités peptidasiques intracellulaires de Streptococcus thermophilus. Purification et propriétés d'une dipeptidehydrolase et d'une aminopeptidase. Biochimie $55,389-404$

Radke-Mitchell L, Sandine WE (1984) Associative growth and differential enumeration of Streptococcus thermophilus and Lactobacillus bulgaricus: a review. J Food Prot 47, 245248

Ragout A, Pesce de Ruiz Holgado A, Oliver G, Sineriz F (1989) Presence of an $L(+)$-lactate dehydrogenase in cells of Lactobacillus delbrueckii ssp bulgaricus. Biochimie 71, 639 644

Rajagopal SN, Sandine WE (1990) Associative growth and proteolysis of Streptococcus thermophilus and Lactobacillus bulgaricus in skim milk. J Dairy Sci 73, 894-899

Ramana Rao MV, Dutta SM (1981) Purification and properties of beta-galactosidase from Streptococcus thermophilus. J Food Sci 46, 1419-1423

Rao DR, Pulusani SR (1981) Effect of cultural conditions and media on the antimicrobial activity of Streptococcus thermophilus. J Food Sci 46, 630-632

Rasic J, Vucurovic N (1973) Untersuchung der freien Fettsäuren in Joghurt aus Kuh-, Schafund Ziegenmilch. Milchwissenschaft 28, 220222

Rasic J, Kurmann JA (1978) Yoghurt: Scientific Grounds, Technology, Manufacture and Preparations. Rasic J, Kurmann JA, publ, Tech Dairy Publ House distributors, Copenhagen, Denmark

Rasic J, Stojsavljevic T, Curcic R (1971a) A study on the amino acids of yoghurt. II. Amino acids content and biological value of the proteins of different kinds of yoghurt. Milchwissenschaft 26, 219-224

Rasic J, Curcic R, Stojsavljevic T, Obradovic B (1971b) A study on the amino acids of yoghurt. III. Amino acids content and biological value of the proteins of yoghurt made from goat's milk. Milchwissenschaft 26, 496-499
Raya RR, Manca De Nadra MC, Pesce De Ruiz Holgado A, Oliver G (1986) Acetaldehyde metabolism in lactic acid bacteria. Milchwissenschaft 41, 397-399

Reddy GV, Shahani KM (1971) Isolation of an antibiotic from Lactobacillus bulgaricus. J Dairy Sci 54, 748

Reddy GV, Shahani KM, Friend BE, Chandan RC (1983) Natural antibiotic activity of Lactobacillus acidophilus and bulgaricus. III. Production and partial purification of bulgarican from Lactobacillus bulgaricus. Cult Dairy Prod J 18, 15-19

Reiter B, Oram JD (1962) Nutritional studies on cheese starters. I. Vitamin and amino acid requirements of single strain starters. J Dairy Res 29, 63-77

Ritchey TW, Seeley HW Jr (1976) Distribution of cytochrome-like respiration in streptococci. J Gen Microbiol 93, 195-203

Rysstad G, Abrahamsen RK (1987) Formation of volatile aroma compounds and carbon dioxide in yogurt starter grown in cows' and goats' milk. J Dairy Res 54, 257-266

Rysstad G, Knutsen WJ, Abrahamsen RK (1990) Effect of threonine and glycine on acetaldehyde formation in goats' milk yogurt. $J$ Dairy Res 57, 401-411

Sanders ME (1989) Bacteriophage resistance and its applications to yogurt flora. In: Yogurt: Nutritional and Health Properties (Chandan RC, ed) Nat Yogurt Assoc, USA, 57-67

Schellhaass SM (1983) Characterization of exocellular slime produced by bacterial starter cultures used in the manufacture of fermented dairy products. PhD Thesis, Univ Minnesota, MN, USA

Schleifer KH, Kilpper-Bälz R (1987) Molecular and chemotaxonomic approaches to the classification of streptococci, enterococci and lactococci: a review. Syst Appl Microbiol 10, 1 19

Schmidt BF, Adams RM, Requadt C, Power S, Mainzer SE (1989) Expression and nucleotide sequence of the Lactobacillus bulgaricus $\beta$-galactosidase gene cloned in Escherichia coli. J Bacteriol 171, 625-635

Séchaud L (1990) Caractérisation de 35 bactériophages de Lactobacillus helveticus. Thèse doctorat, Univ Paris VII et XI - ENSIAA Massy, France 
Shahbal S, Hemme D, Desmazeaud M (1991) High cell wall-associated proteinase activity of some Streptococcus thermophilus strains (H-strains) correlated with a high acidification rate in milk. Lait 71, 351-357

Shankar PA, Davies FL (1977) Amino acid and peptide utilization by Streptococcus thermophilus in relation to yoghurt manufacture. $J$ Appl Bacteriol 43, viii

Shankar PA, Davies FL (1978) Relation entre Streptococcus thermophilus et Lactobacillus bulgaricus dans les levains du yoghourt. $20^{\circ}$ Congr Int Lait F, 521-522

Shimizu-Kadota M, Sakurai T (1982) Prophage curing in Lactobacillus casei by isolation of a thermoinducible mutant. Appl Environ Microbiol 43, 1284-1287

Shimizu-Kadota M, Kiwaki M, Hirokawa H, Tsuchida N (1985) ISL 1: a new transposable element in Lactobacillus casei. Mol Gen Genet 200, 193-198

Simonds J, Hansen PA, Lakshmanan S (1971) Deoxyribonucleic acid hybridization among strains of lactobacilli. J Bacteriol 107, 382384

Sissons $\mathrm{CH}$, Loong PC, Hancock EM, Cutress TW (1989) Electrophoretic analysis of ureases in Streptococcus salivarius and in saliva. Oral Microbiol Immunol 4, 211-218

Smaczny T, Krämer J (1984a) Säuerungsstörungen in der Joghurt-, Bioghurt- und Biogarde- Produktion, bedingt durch Bacteriocine und Bakteriophagen von Streptococcus thermophilus. I. Verarbeitung und Charakterisierung der Bacteriocine. Dtsch Molk-Ztg $105,460-461,464$

Smaczny $T$, Krämer $J$ (1984b) Säuerungsstörungen in der Joghurt-, Bioghurtund Biogarde- Produktion, bedingt durch Bacteriocine und Bakteriophagen von Streptococcus thermophilus. II. Verbreitung und Charakterisierung der Bacteriophagen. Dtsch Molk-Ztg 105, 614-618

Smart JB, Thomas TD (1987) Effect of oxygen on lactose metabolism in lactic streptococci. Appl Environ Microbiol 53, 533-541

Smart JB, Crow VL, Thomas TD (1985) Lactose hydrolysis in milk and whey using $\beta$ galactosidase from Streptococcus thermophilus. NZ J Dairy Sci Technol 20, 43-56
Somkuti GA, Steinberg DH (1979) Adaptability of Streptococcus thermophilus to lactose, glucose and galactose. J Food Prot 42, 881882,887

Somkuti GA, Steinberg DH (1986a) Distribution and analysis of plasmids in Streptococcus thermophilus. J Ind Microbiol 1, 157-163

Somkuti GA, Steinberg DH (1986b) General method for plasmid DNA isolation from thermophilic lactic acid bacteria. J Biotechnol 3, 323-332

Spillmann H, Puhan Z, Banhegyi M (1978) Antimikrobielle Aktivität thermophiler Laktobazillen. Milchwissenschaft 33, 148-153

Spinnler HE, Corrieu G (1989) Automatic method to quantify starter activity based on $\mathrm{pH}$ measurement. J Dairy Res 56, 755-764

Spinnler HE, Bouillanne C, Desmazeaud MJ, Corrieu G (1987) Measurement of the partial pressure of dissolved $\mathrm{CO}_{2}$ for estimating the concentration of Streptococcus thermophilus in coculture with Lactobacillus bulgaricus. Appl Microbiol Biotechnol 25, 464-470

Stadhouders J, Hassing F, Leenders GJM, Driessen FM (1984) Disturbance of acid production by bacteriophages in the manufacture of yogurt. Zuivelzicht 2, 40-43

Stadhouders J, Smalbrink L, Maessen-Damsma G, Klompmaker T (1988) Phage prevention at the manufacture of yogurt. Voedingsmiddelentechnologie 21, 21-24

Suzuki I, Ando T, Fujita Y, Kitada T, Morichi T (1982) Symbiotic and antagonistic relationships in mixed cultures of Lactobacillus bulgaricus and Streptococcus thermophilus. Jpn J Zootech Sci 53, 161-169 (Dairy Sci Abstr $\left.44, N^{\circ} 6246\right)$

Suzuki I, Kato S, Kitada T, Yano N, Morichi T (1986) Growth of Lactobacillus bulgaricus in milk. 1. Cell elongation and the role of formic acid in boiled milk. J Dairy Sci 69, 311-320

Szylit O, Nugon-Baudon L (1985) Lactobacillus contribution to the nutritional physiopathology of the host. A review. Sci Aliments 5 (suppl V), 257-262

Tamime AY, Deeth HC (1980) Yogurt: technology and biochemistry. J Food Prot 43, 939-977

Tamime AY, Robinson RK (1985) Yoghurt. Science and Technology. Pergamon Press, Oxford 
Teggatz JA, Morris HA (1990) Changes in the rheology and microstructure of ropy yogurt during shearing. Food Struct 9, 133-138

Teraguchi S, Ono J, Kiyosawa I, Okonogi S (1987) Oxygen uptake activity and aerobic metabolism of Streptococcus thermophilus STH450. J Dairy Sci 70, 514-523

Thomas TD, Crow VL (1983) Lactose and sucrose utilization by Streptococcus thermophiIUS. FEMS Microbiol Lett 17, 13-17

Thomas TD, Crow VL (1984) Selection of galactose-fermenting Streptococcus thermophilus in lactose-limited chemostat cultures. Appl Environ Microbiol 48, 186-191

Thompson J (1987) Sugar transport in the lactic acid bacteria. In: Sugar Transport and Metabolism in Gram-positive Bacteria (Reizer J, Peterkofski A, eds) Halsted Press, John Wiley, New York, 13-38

Tinson W, Hillier AJ, Jago GR (1982a) Metabolism of Streptococcus thermophilus. 1. Utilization of lactose, glucose and galactose. Aust J Dairy Technol 37, 8-13

Tinson W, Broome MC, Hillier AJ, Jago GR (1982b) Metabolism of Streptococcus thermophilus. 2. Production of $\mathrm{CO}_{2}$ and $\mathrm{NH}_{3}$ from urea. Aust J Dairy Technol 37, 14-16

Turcic M, Rasic J, Canic V (1969) Influence of Str thermophilus and $L b$ bulgaricus culture on volatile acids content in the flavour components of yoghurt. Milchwissenschaft 24, 277-281

Vedamuthu ER, Neville JM (1986) Involvement of a plasmid in production of ropiness (mucoidness) in milk cultures by Streptococcus cremoris MS. Appl Environ Microbiol 51, 677-682

Veringa HA, Galesloot TE, Davelaar H (1968) Symbiosis in yoghurt. (II). Isolation and identification of a growth factor for Lactobacillus bulgaricus produced by Streptococcus thermophilus. Neth Milk Dairy J 22, 114-120

Vescovo M, Bottazzi V, Sarra PG, Dellaglio F (1981) Evidence of plasmid deoxyribonucleic acid in Lactobacillus. Microbiologica 4, 413419

Vescovo M, Scolari GL, Bottazzi V (1989) Plasmid-encoded ropiness production in Lactobacillus casei ssp casei. Biotechnol Lett 11, 709-712

Weiss N, Schillinger U, Kandler O (1983) Lactobacillus lactis, Lactobacillus leichmanii and Lactobacillus bulgaricus, subjective synonyms of Lactobacillus delbrueckii, and description of Lactobacillus delbrueckii subsp lactis comb nov and Lactobacillus delbrueckii subsp bulgaricus comb nov. Syst Appl Microbiol 4, 552-557

Whittenbury R (1978) Biochemical characteristics of Streptococcus species. In: Streptococci (Skinner FA, Quesnel LB, eds) Academic Press, New York, 51-69

Wilkins DW, Schmidt RH, Kennedy LB (1986a) Threonine aldolase activity in yogurt bacteria as determined by headspace gas chromatography. J Agric Food Chem 34, 150-152

Wilkins DW, Schmidt RH, Shireman RB, Smith KL, Jezeski JJ (1986b) Evaluating acetaldehyde synthesis from $L-\left[{ }^{14} \mathrm{C}(\mathrm{U})\right]$ threonine by Streptococcus thermophilus and Lactobacillus bulgaricus. J Dairy Sci 69, 1219-1224

Zourari A (1991) Caractérisation de bactéries lactiques thermophiles isolées à partir de yaourts artisanaux grecs. Thèse Doctorat INA-PG, Paris-Grignon, France

Zourari A, Desmazeaud MJ (1991) Caractérisation de bactéries lactiques thermophiles isolées de yaourts artisanaux grecs. II. Souches de Lactobacillus delbrueckii subsp bulgaricus et cultures mixtes avec Streptococcus salivarius subsp thermophilus. Lait 71, 463-482

Zourari A, Roger S, Chabanet C, Desmazeaud MJ (1991) Caractérisation de bactéries lactiques thermophiles isolées de yaourts artisanaux grecs. I. Souches de Streptococcus salivarius subsp thermophilus. Lait 71, 445-461 